\title{
Geochemistry and magnetostratigraphy of Deccan flows at Anjar, Kutch
}

\author{
A D Shukla, N Bhand A R I**, Shemla Kusumgar, P N ShuKLA, \\ Z G GHEVARIYA*, K G OPALA N ${ }^{\dagger}$ and V B A L A R A M \\ Physical Research Laboratory, Navrangpura, Ahmedabad, 380 009, India \\ * Geological Survey of India, Gandhinagar 382043, India \\ ${ }^{\dagger}$ National Geophysical Research Institute, New Uppal Road, Hyderabad 500 00\%, India \\ **e-mail: bhandari@prl.ernet.in
}

Chemical analysis of nine Deccan flow basalts at Anjar, Kutch, western India, indicates that all, except the uppermost flow F-9, are alkaline. In their major and trace element composition, the alkali basalts resemble Ocean island basalts (OIB). Similarities of many diagnostic trace element ratios (e.g. $\mathrm{Sm} / \mathrm{Nd}, \mathrm{Ba} / \mathrm{Nb}, \mathrm{Y} / \mathrm{Nb}$ and $\mathrm{Zr} / \mathrm{Nb}$ ) are similar to those found in the Réunion Island basalts. The uppermost basalt is tholeiitic and chemically resembles the least contaminated Deccan basalt (Ambenali type). The Anjar basalts have iridium concentration ranging between 2 and $178 \mathrm{pg} / \mathrm{g}$. Some of these values are higher by about an order of magnitude compared to the Ir concentration in other basalts of the Deccan. A synthesis of chemical, palaeomagnetic and geochronologic data enables us to construct a chemical and magnetic stratigraphy for these flows.

The three flows below the iridium enriched intertrappean bed (IT III) show normal magnetic polarity whereas all except one of the upper basalts show reversed magnetic polarity. The sequence seems to have started in polarity zones $31 \mathrm{~N}$ and probably continued up to $28 \mathrm{R}$ or $27 \mathrm{R}$. The results presented here support the view that Deccan volcanism in Kutch occurred on a time span of a few million years.

\section{Introduction}

Deccan volcanism in India represents one of the largest areas $\left(>10^{6} \mathrm{~km}^{2}\right)$ of continental flood basalts. The initial area covered by Deccan volcanics is estimated to be about $2 \times 10^{6} \mathrm{~km}^{2}$, about half of which has been eroded during the last 60 million years. The initial volume of the basalt, considering its unexposed part and erosional losses, is estimated at over $\sim 2 \times 10^{6} \mathrm{~km}^{3}$ (Sen 1995) although some estimates are extremely high at about $8 \times 10^{6} \mathrm{~km}^{3}$ (Coffin and Eldholm 1993). The flows of western Ghats (Ambenali, Mahabaleshwar, Igatpuri, Poladpur etc.) have been mapped in detail and characterized using chemical, mineralogical, palaeomagnetic and geochronological studies (Cox and Hawkesworth 1985; Duncan and Pyle 1988; Subbarao et al 1988; Vandamme et al 1991, Venkatesan et al 1993, Baksi 1994, Venkatesan and Pande 1996). Though some work has also been done on basalts from the northeastern Trap province (Nagpur, Jabalpur, Salbardi etc; Yedekar et al 1996; Deshmukh and Nair 1996; Peng et al 1998), the basalts from Kutch and Saurashtra regions, except for a few studies (Krishnamurthy and Cox 1977, 1980; Krishnamurthy et al 1988; Melluso et al 1995; Peng and Mahoney 1995), have not been investigated in detail. We have carried out chemical and palaeomagnetic studies of the Trap sequence at Anjar in Kutch (figure 1). Geochronological dating of this sequence has been done by Venkatesan et al (1996); Venketasan and Pande (private communication) and Hofmann (1997). The Anjar volcano-sedimentary sequence has attained importance in the context of identification of iridium-rich layers in one of the intertrappean beds (IT-III) and its possible association with the Cretaceous-Tertiary (K/T) boundary event since this is the only $\mathrm{K} / \mathrm{T}$ site in Deccan identified so far (Bhandari et al 1995, 1996). All these results are synthesized and discussed here.

The Deccan volcanics are predominantly composed of tholeiitic basalts and alkaline, acidic and carbonatitic lavas form only minor components. It

Keywords. Anjar flows; K/T boundary; alkali basalts; magnetostratigraphy; geochemistry; ocean island basalts; Réunion plume.

Proc. Indian Acad. Sci. (Earth Planet. Sci.), 110, No. 2, June 2001, pp. 111-132

(C) Printed in India. 


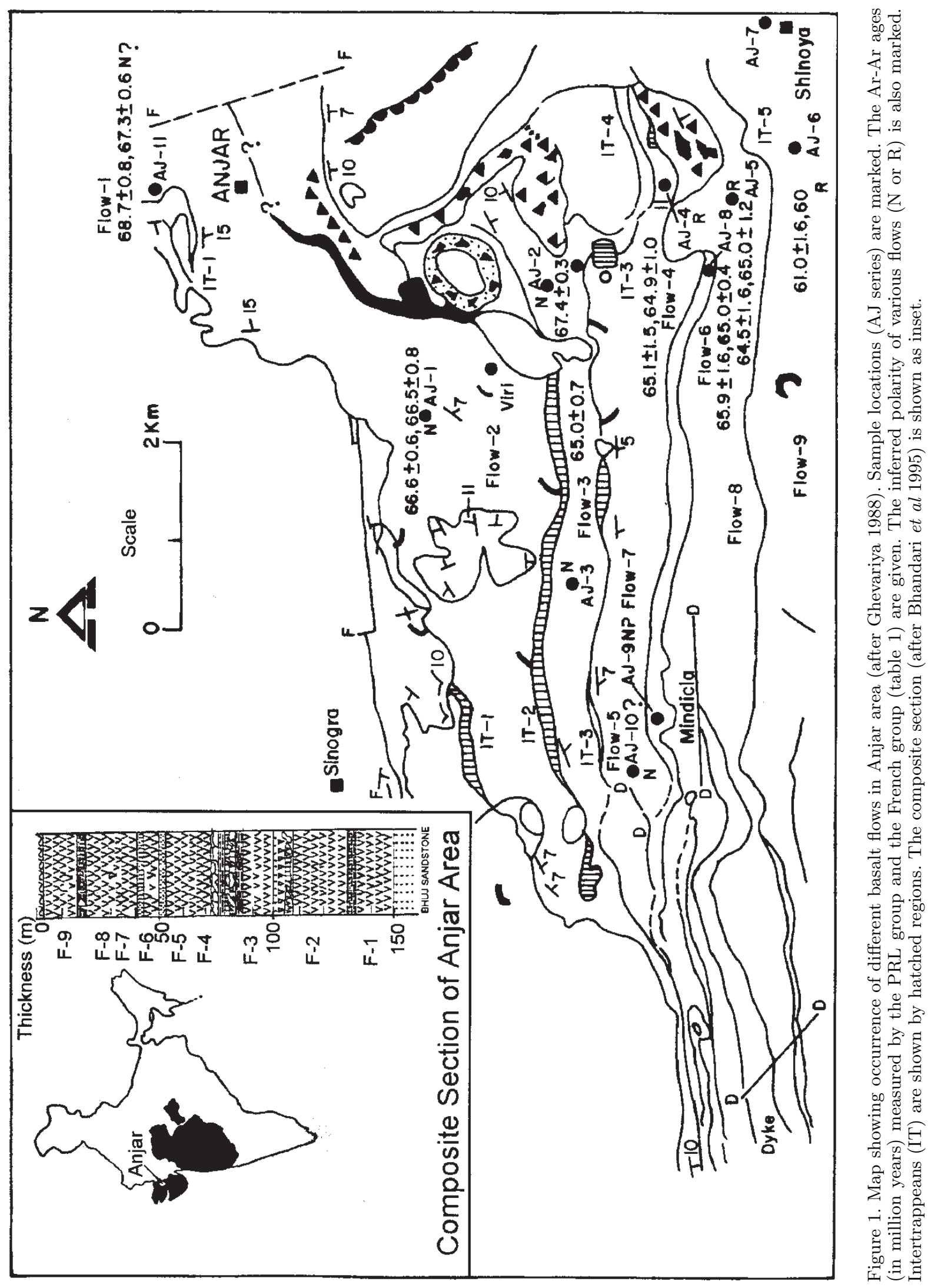


has been proposed that Deccan traps are related to the Réunion Plume (Morgan 1972, 1981; Duncan 1981; Campbell and Griffiths 1990; Basu et al 1993). The plume head formed the flood basalts and the trail of the plume has generated the track that ends in the active volcanoes on the Réunion Island. The plume origin is supported by the high ${ }^{3} \mathrm{He} /{ }^{4} \mathrm{He}$ ratio, which is characteristic of the deep mantle (Basu et al 1993) besides other geochemical signatures (Peng et al 1994; Peng and Mahoney 1995).

The duration of Deccan volcanism has been a matter of intense debate. Based on magnetoand chrono-stratigraphy, Duncan and Pyle (1988), Courtillot et al (1988), Vandamme et al (1991), Allègre et al (1999) and Hofmann et al (2000) have proposed a short $(\leq 0.5 \mathrm{Ma})$ duration for the peak volcanic activity of the Deccan. This conclusion relies on the fact that most of the Deccan flows show a reverse magnetic polarity and only in a few sections, a maximum of two reversals (N-R-N sequence) has been seen. There is some controversy about true radiometric ages and duration of Deccan flows. The frequency distribution of ${ }^{40} \mathrm{Ar}^{39} \mathrm{Ar}$ ages compiled by Courtillot et al (1986, 1988, 1996) and Duncan and Pyle (1988) show a peak at 65Ma. Venkatesan and Pande (1996), considering only the reliable ages of the basal part of the Western Ghats composite section comprising Jawhar, Igatpuri, Neral and Thakurwadi formations, generated in various laboratories based on ${ }^{40} \mathrm{Ar}-{ }^{39} \mathrm{Ar}$ technique, have suggested that this basal section predates the Cretaceous/Tertiary transition by about 1.3 Ma. They further argued that this basal part of the section belongs to the $30 \mathrm{R}$ reversed polarity magnetic chron rather than 29R as suggested by Courtillot et al $(1986,1988)$. As this basal part of the Western Ghats comprises most of the flow volume, it is likely that the main pulse of Deccan came before the $\mathrm{K} / \mathrm{T}$ transition. The considerably younger ages of the upper part of the section imply that the Deccan volcanism extended over 3 to 4 million years.

Raju et al (1991, 1995) have used the fossil evidence of intertrappean sediment beds in the Krishna-Godavari basin and concluded that the Deccan flows were emplaced during an extended time period of 5-7 Ma. Their conclusions generally support the longer duration proposed by Venkatesan et al (1993) and are not consistent with rapid volcanism $(\leq 0.5 \mathrm{Ma})$. The dates of Deccan flows from the eastern margin of Deccan (Takli, Salbardi etc) also show a span of 3-4 Ma, the ages lying between 63 and $67 \mathrm{Ma}$ ( Shukla et al 1988; Kaneoka et al 1996). However, little ${ }^{40} \mathrm{Ar}-{ }^{39} \mathrm{Ar}$ work has been done on Kutch basalts. A few dates by Pande et al (1988) show ages ranging between 64.4 and 67.7 Ma.

The iridium (osmium and other platinum group elements) contribution of the Deccan is another question that is quite important in connection with the $\mathrm{K} / \mathrm{T}$ event and mass extinction. The global inventory of iridium at KTB is estimated to be around 250,000 tons taking its average integrated flux to be $50 \mathrm{ng} / \mathrm{cm}^{2}$. Orth et al (1990) find that iridium concentration of Deccan basalts is low, around $3 \mathrm{pg} / \mathrm{g}$. Their measurements are confined to tholeiitic basalts. Not only is the iridium content of basalts low, but even the intertrappean sediments (marl, clay and shale etc) at a number of sites show a low (usually $<30 \mathrm{pg} / \mathrm{g}$ ) iridium concentration (Rocchia et al 1988) although values as high as $120 \mathrm{pg} / \mathrm{g}$ have been found in Takli intertrappeans at Nagpur (Bhandari et al 1993). The intertrappeans of Anjar, however, show high concentration of iridium up to $1333 \mathrm{pg} / \mathrm{g}$ (Bhandari et al 1995, 1996). They found three thin primary sub-centimeter thick ferruginous layers separated by $25-32 \mathrm{~cm}$, rich in iridium, in the third intertrappean bed at Anjar. Not only are the Ir and Os high in these layers, but the intertrappean bed as a whole generally has a higher concentration of Ir, around $100 \mathrm{pg} / \mathrm{g}$. Various arguments based on geochronology, anomalous PGE (platinum group elements) concentrations and fossil evidence suggest that the third intertrappean bed at Anjar encompasses the Cretaceous-Tertiary boundary (Bhandari et al 1995, 1996; Shukla et al 1997; Shukla and Bhandari 1997).

The Anjar volcano-sedimentary sequence has been mapped by Ghevariya and Srikarni (1989). Based on their work, it appears that there are at least seven, and possibly as many as eleven basalt flows, five of which have well developed intertrappean beds, several meters in thickness. The sequence was deposited in a lacustrine environment under semi-arid conditions (Khadkikar et al 1999). Volcanogenic clay minerals in this section have been reported by Shrivastava et al (2000) which can be expected since the whole sedimentary sequence was deposited in a volcanic environment. Some of the basalt flows are thin and limited in extent whereas others are compound flows. In the absence of a vertical section containing the entire sequence, it is difficult to identify or distinguish various basalts based on field observations. Bhandari et al (1995) have constructed a composite section based on the field observations of Ghevariya (1988) considering the seven well recognized flows. To characterize different flows, we have now carried out their detailed chemical analysis and discuss here some questions related to their stratigraphic relationship and origin. 
Table 1. Flow assignments of various samples and their radiometric ages.

\begin{tabular}{|c|c|c|c|c|}
\hline Flow \# & Sample code & Age $(\mathrm{Ma})^{2}$ & Remark & Assigned age \\
\hline F9 & $\begin{array}{l}\text { KP-7 } \\
\text { KP-7' } \\
\text { AJ6-3 } \\
\text { AJ 6-8 } \\
\text { AJ6-9 }\end{array}$ & $\begin{array}{l}61 \pm 1.6^{5}(\mathrm{WR}) \\
60+2.0 \\
60^{4} \\
(\mathrm{PL} \& \mathrm{WR})\end{array}$ & $\begin{array}{l}\text { Integrated Age } \\
\text { Estimated Age }\end{array}$ & $61 \pm 1.6$ \\
\hline F8 & $\begin{array}{l}\text { F-6 H.S. } \\
\text { KP-6 } \\
\text { KP- } 6^{\prime}\end{array}$ & $\begin{array}{l}65.0 \pm 1.2^{5}(\mathrm{WR}) \\
64.5 \pm 1.6^{4}(\mathrm{WR})\end{array}$ & $\begin{array}{l}\text { Integrated Age } \\
\text { Estimated Age }\end{array}$ & $64.8 \pm 1.0$ \\
\hline F7 & $\begin{array}{l}\text { AJ9-11 } \\
\text { AJ9-12 } \\
\text { AJ9-2 }\end{array}$ & & & \\
\hline F6 & $\begin{array}{l}\text { AJ 8-12 } \\
\text { AJ 8-7 } \\
\text { AJ 8-4 } \\
\text { KP-5 } \\
\text { KP-5' }\end{array}$ & $\begin{array}{l}65.0+0.4^{4}(\mathrm{WR}) \\
65.9 \pm 1.6^{5}(\mathrm{WR})\end{array}$ & $\begin{array}{l}\text { Estimated Age } \\
\text { Integrated Age }\end{array}$ & $65.1 \pm 0.4$ \\
\hline F5 & $\begin{array}{l}\text { AJ10-1 } \\
\text { F-4B }\end{array}$ & & & \\
\hline $\mathrm{F} 4$ & $\begin{array}{l}\mathrm{F}-4 \mathrm{KP}^{\prime} \\
\mathrm{F}-4 \mathrm{KP} 4 \\
\text { AJ } 4-1 \\
\text { AJ } 4-5 \\
\text { F-4A' } \\
\text { F-4 }\end{array}$ & $\begin{array}{l}65.7 \pm 0.7^{3}(\mathrm{WR}) \\
64.9 \pm 1.0^{4}(\mathrm{PL})\end{array}$ & $\begin{array}{l}\text { Plateau like Age } \\
\text { Plateau Age }\end{array}$ & $65.4 \pm 0.6$ \\
\hline F3 & $\begin{array}{l}\text { F-3 B } \\
\text { KP-3 } \\
\text { KP3' } \\
\text { AJ3-10 } \\
\text { AJ3-11 } \\
\text { AJ2-14 } \\
\text { AJ2-3 } \\
\text { F3\#32 } \\
\text { F3\#32D }\end{array}$ & $\begin{array}{l}65.2 \pm 0.6^{3}(\mathrm{WR}) \\
64.9 \pm 0.8^{3}(\mathrm{WR}) \\
66.9 \pm 0.2^{4}(\mathrm{WR}) \\
67.4 \pm 0.3^{4}(\mathrm{WR})\end{array}$ & Plateau Age & $65.1 \pm 0.5$ \\
\hline $\mathrm{F} 2$ & $\begin{array}{l}\text { KP-2 } \\
\text { AJ } 1-10 \\
\text { AJ1-15 }\end{array}$ & $\begin{array}{l}66.6 \pm 0.6^{5}(\mathrm{WR}) \\
66.5 \pm 0.8^{4}(\mathrm{PL}) \\
65.3 \pm 0.6^{4}(\mathrm{WR}) \\
66.9 \pm 0.1^{4}(\mathrm{WR})\end{array}$ & $\begin{array}{l}\text { Plateau Age } \\
\text { Plateau Age } \\
\text { Estimated Age } \\
\text { Total Age }\end{array}$ & $66.6 \pm 0.5$ \\
\hline $\mathrm{F} 1$ & $\begin{array}{l}\mathrm{KP}^{\prime} \\
\mathrm{KP}-1 \\
\text { AJ11-1 } \\
\text { AJ11-8 } \\
\text { AJ11-2 }\end{array}$ & $\begin{array}{l}68.7 \pm 0.8^{5}(\mathrm{WR}) \\
66.8 \pm 0.4^{4}(\mathrm{WR}) \\
67.1 \pm 0.1^{4}(\mathrm{WR}) \\
67.3 \pm 0.6^{4}(\mathrm{PL})\end{array}$ & $\begin{array}{l}\text { Plateau Age } \\
\text { Estimated Age } \\
\text { Total Age } \\
\text { Plateau Age }\end{array}$ & $67.8 \pm 0.5$ \\
\hline
\end{tabular}

1 The Flow assignment is based on this work and is different in some cases from that given by Venkatesan et al (1996) and Hofmann (1997).

${ }^{2} \mathrm{PL}$ (plagioclase) and WR(whole rock).

${ }^{3}$ Venkatesan et al (1996).

${ }^{4}$ Hofmann (1997).

${ }^{5}$ Venkatesan and Pande (personal comm.).

\section{Sampling details}

Basalt samples were collected from exposed sections at several locations around Anjar town. The various flows are exposed in a sub-parallel manner in east-west direction, younging towards south as shown in figure 1. Existence of several flows is also clear from the satellite imagery (Shukla et al 1997). On the eastern margin of the region, seven flows can be identified in the field whereas on the western margin, there is additionally a cluster of dykes. The dinosaur pit, where dinosaur bones were first found (Ghevariya 1988), is located south of a ring dyke near the eastern side. For the present 


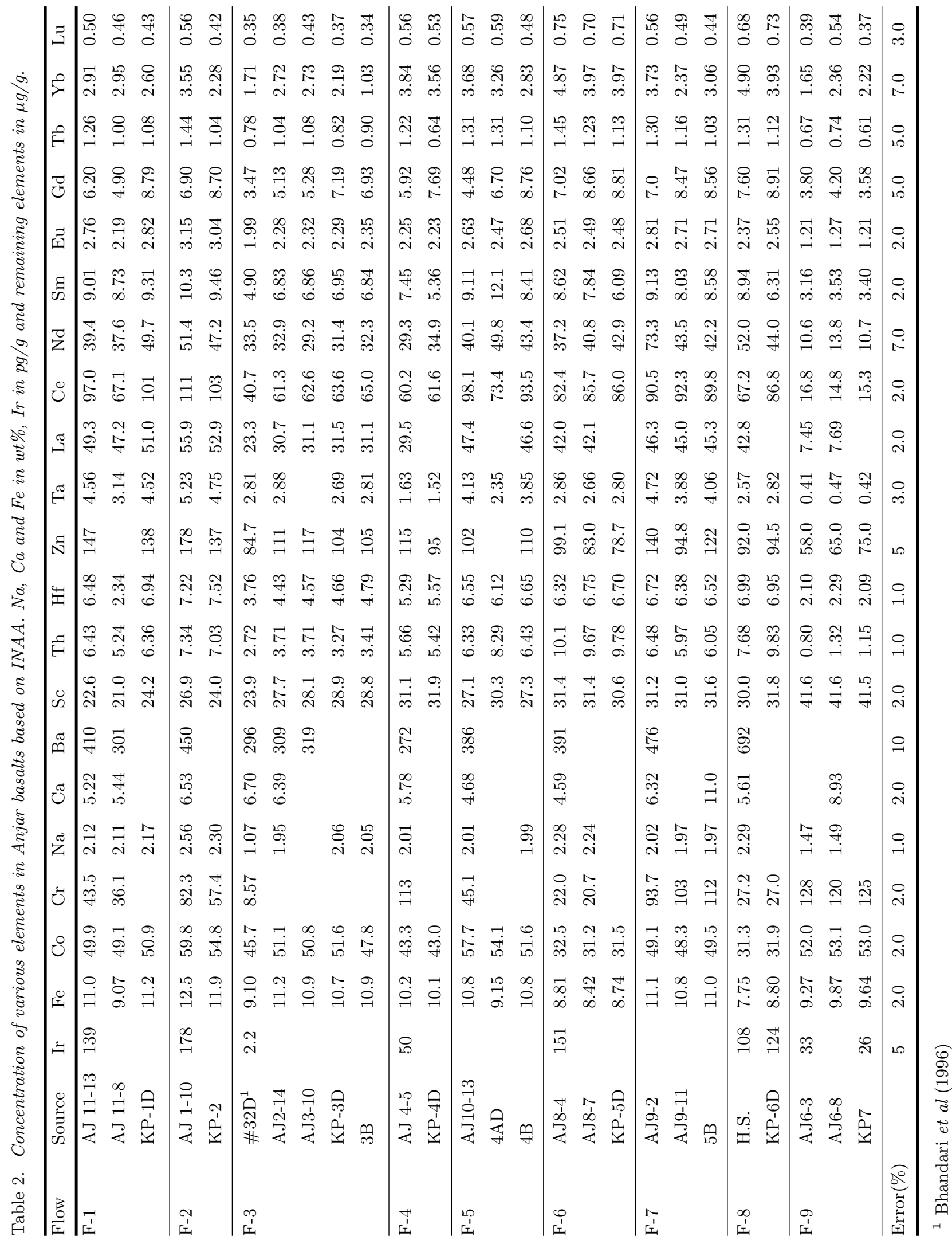




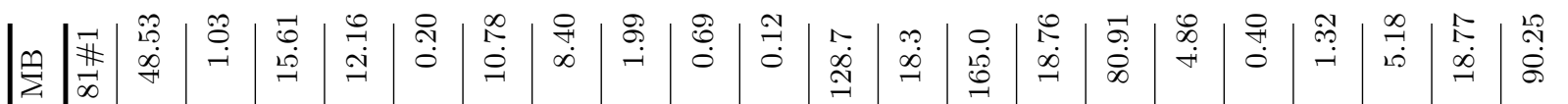

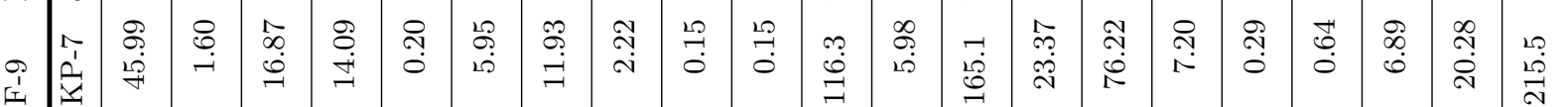

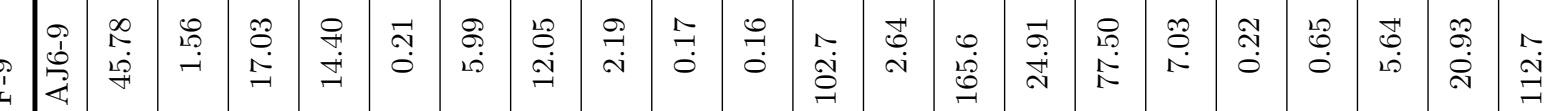

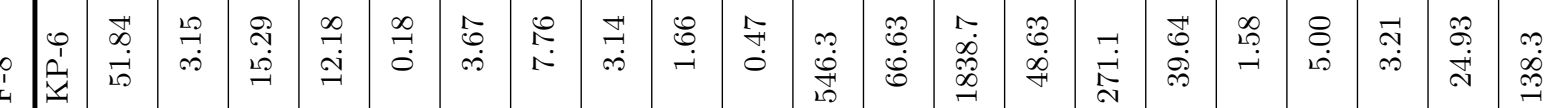

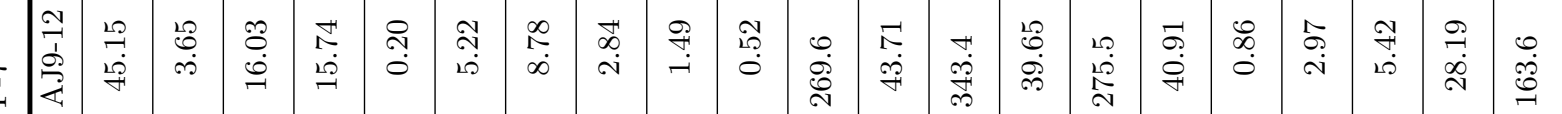

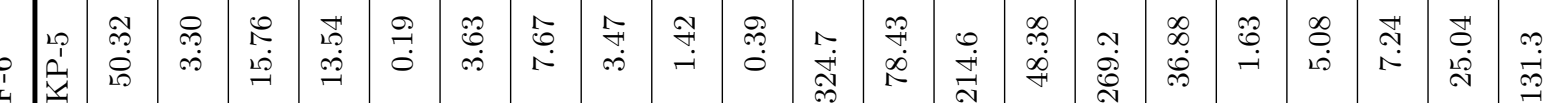

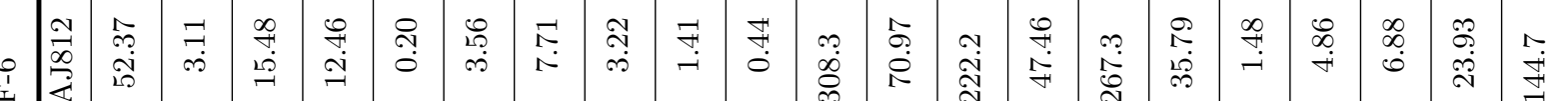

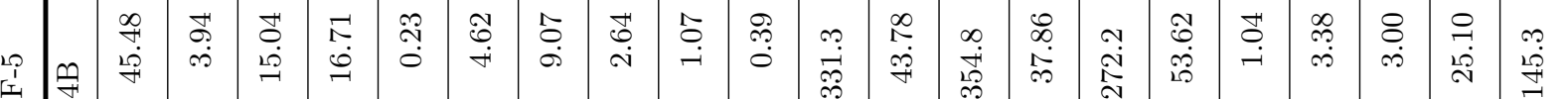

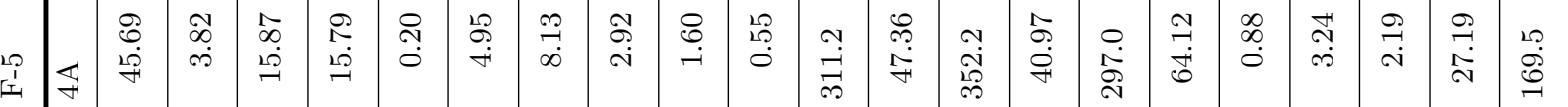

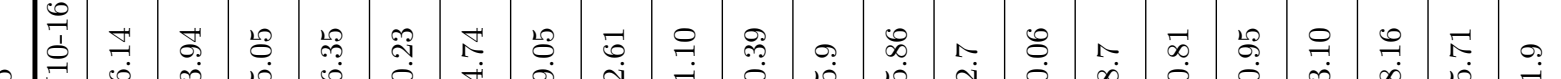

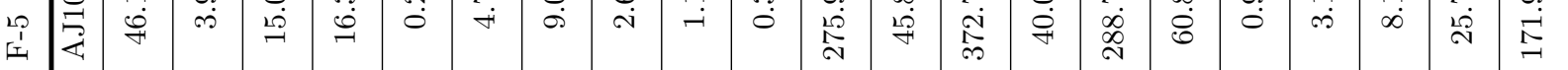

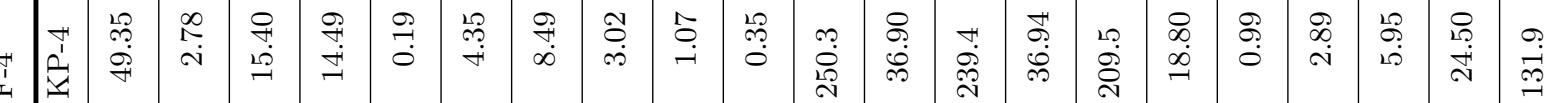

岛

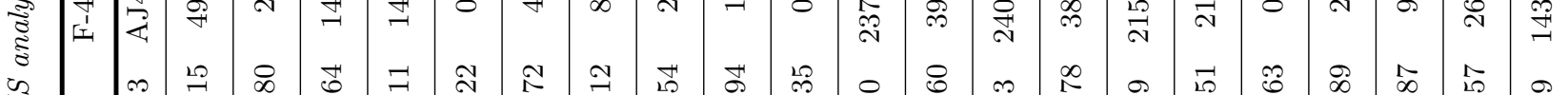

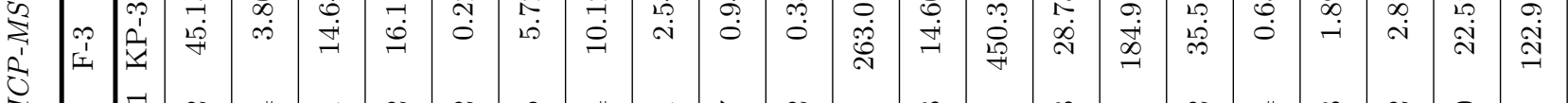

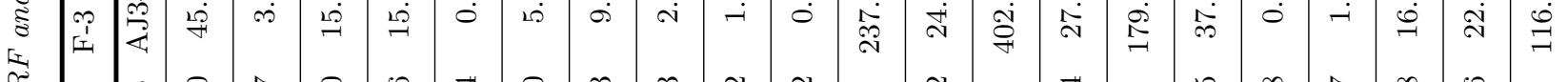

凤

ही

芯

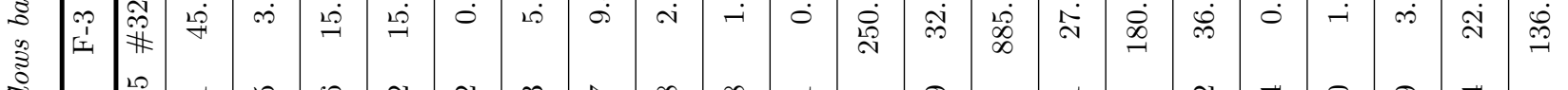

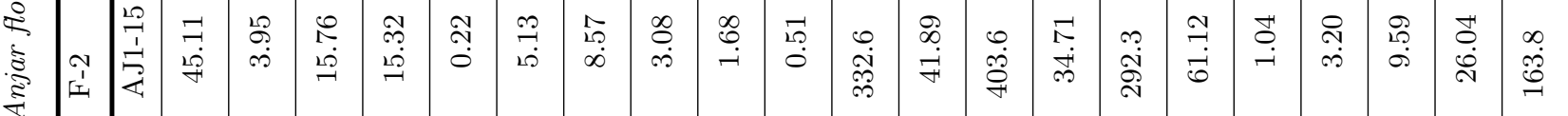

১ I

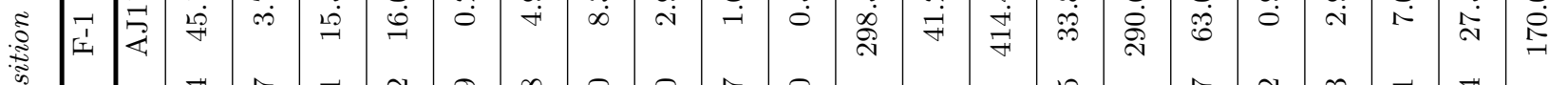

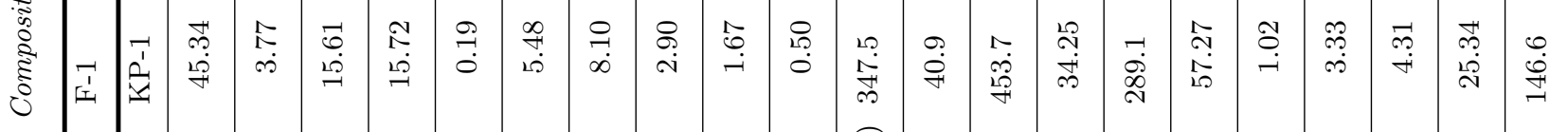

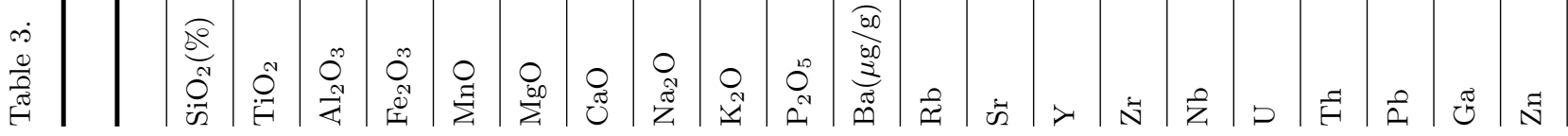




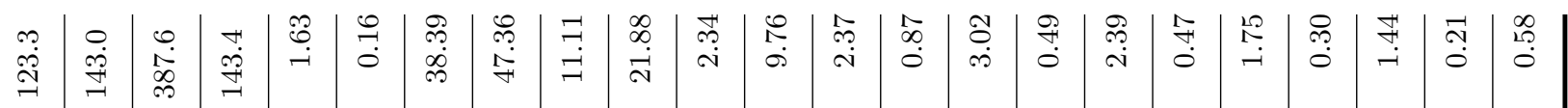

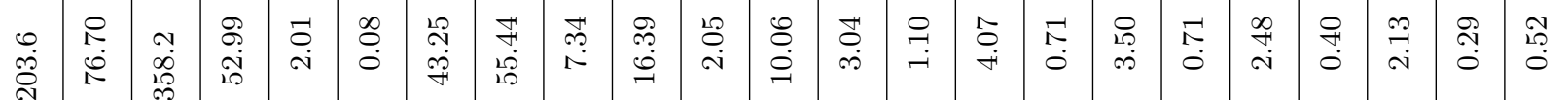

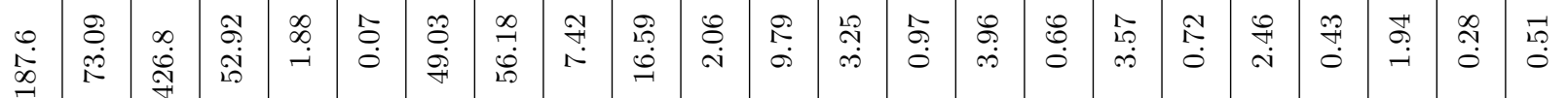

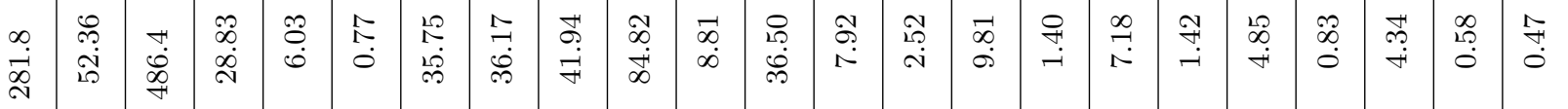

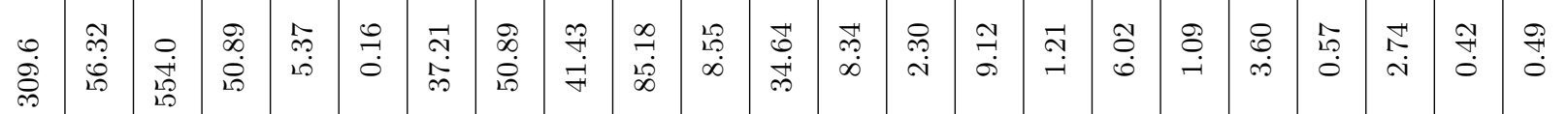

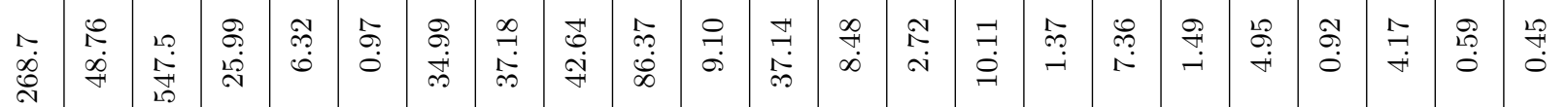

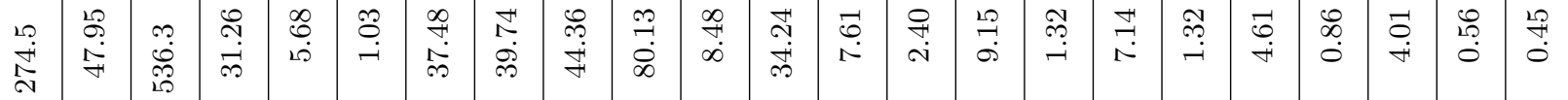

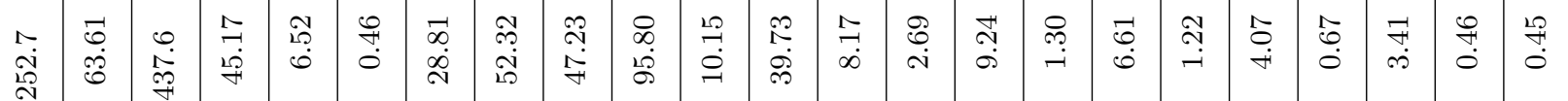

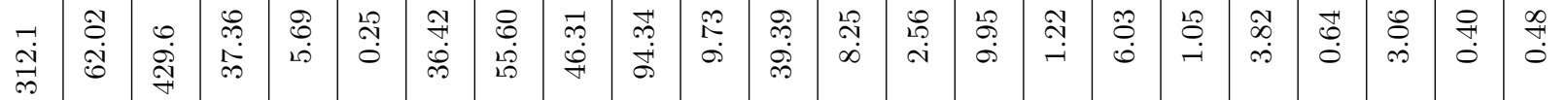

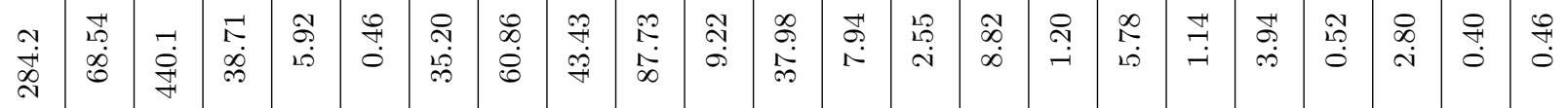

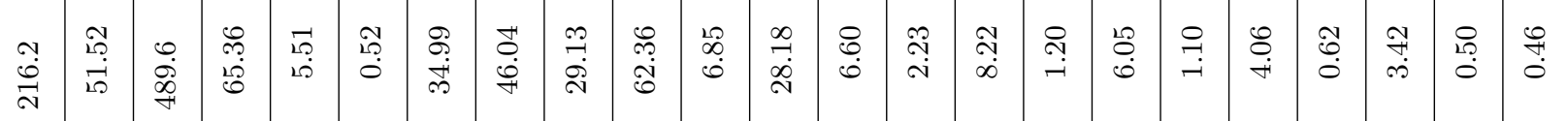

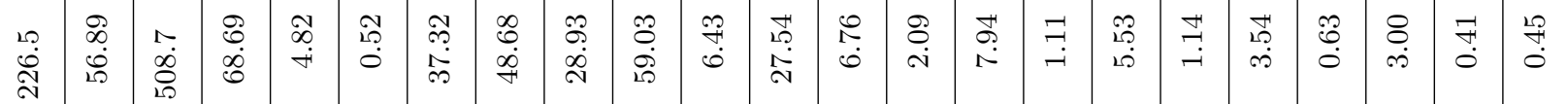

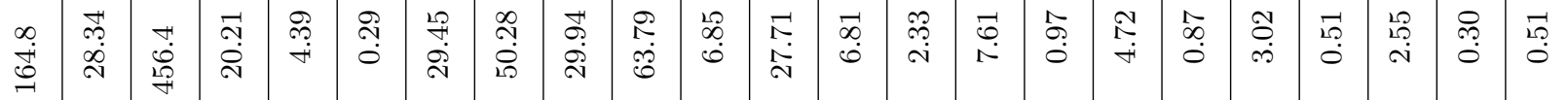

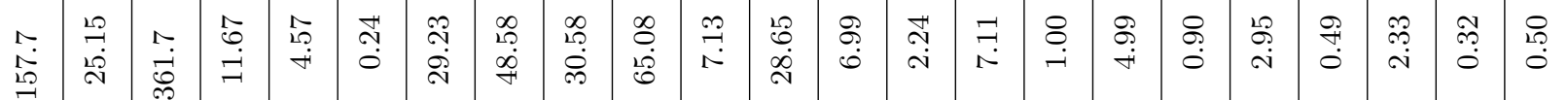

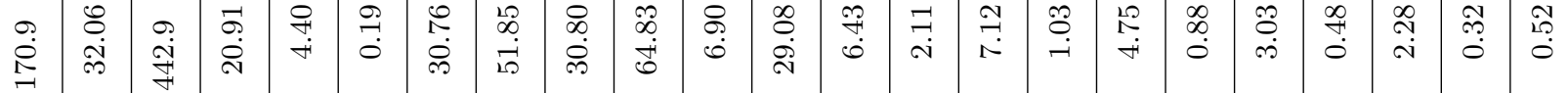

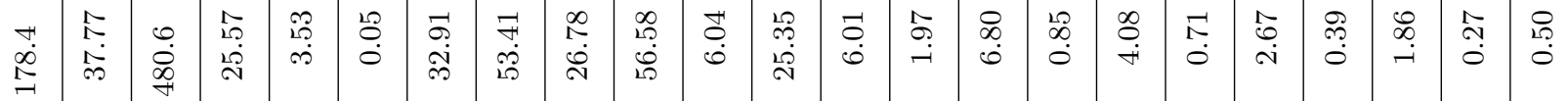

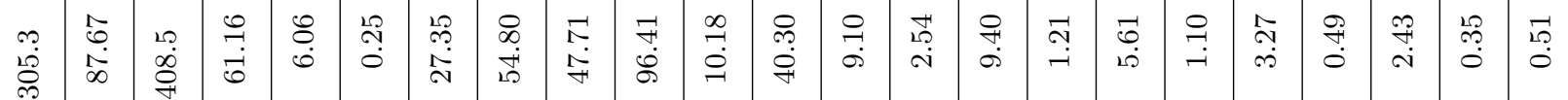

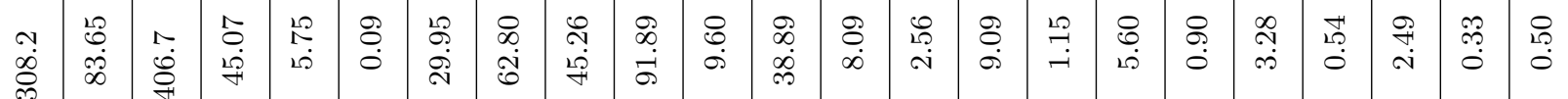

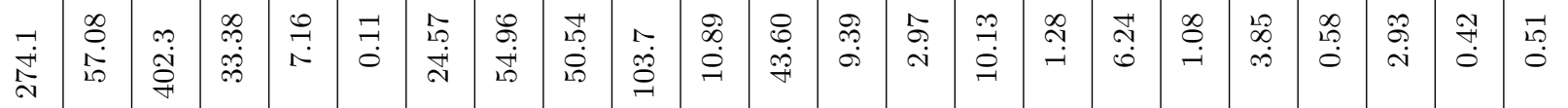

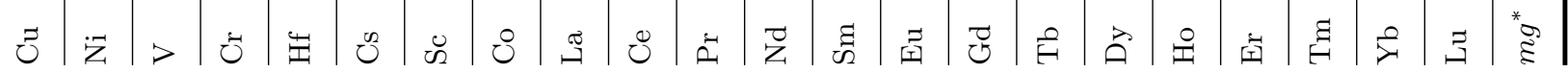


study, several hand specimens were collected during 1991-93 for chemical analysis and in June 1994 for magnetic polarity studies and ${ }^{40} \mathrm{Ar}-{ }^{39} \mathrm{Ar}$ dating. Subsequently, 11 oriented drill cores (AJ series) for palaeomagnetic and geochronological studies were collected in April 1995 jointly with the French team of Gallet, Rocchia, Feraud and Hofmann. Several samples (KP series), appearing relatively less weathered were also collected from nearby locations for ${ }^{40} \mathrm{Ar}-{ }^{39} \mathrm{Ar}$ dating by K. Pande. Two northsouth traverses were made and wherever possible the samples were collected from the west and east margins of each flow as shown in figure 1. A number of samples from various intertrappeans (IT 1, 2, 3, 5 and 6 ) were also collected for chemical and mineralogical analysis. The results of analysis of intertrappeans will be discussed elsewhere and here we confine ourselves to the basalt samples from various flows. The sample locations are shown in figure 1. The flow assignment for various samples and their ${ }^{40} \mathrm{Ar}-{ }^{39} \mathrm{Ar}$ ages measured by Venkatesan et al (1996), Venkatesan and Pande (personal communication) and Hofmann (1997) are given in table 1. Chemical and field studies carried out here indicate that there are nine flows, one or two of which could possibly be dykes. The flow assignment (except for the lower three flows) in this work is therefore not the same as that of Hofmann (1997) and Bhandari et al $(1995,1996)$.

\section{Experimental techniques}

Thirty six samples belonging to the nine flows collected from different locations were analyzed for their chemical composition using neutron activation analysis (INAA), inductively coupled plasma mass spectrometer (ICPMS) or X-ray fluorescence (XRF) methods. Standard procedures were used for neutron activation analyses. Powder samples (typically 200mg) were irradiated in the CIRUS reactor of the Bhabha Atomic Research Centre, Bombay with a neutron fluence of $\sim 10^{18}$ neutrons, together with BCR, Allende meteorite and other standards (AGV, SDO) kindly provided by the U.S. Geological Survey. The concentrations of various elements, listed in table 2, were estimated by periodical gamma ray spectrometry of the irradiated samples using a hyper pure coaxial germanium diode (relative efficiency 48\%) and a low energy planar detector. Sixteen samples were analyzed in this way by INAA and Ir was also measured in all the flows following radiochemical separation (Bhandari et al 1994). Measurements of major and trace elements (table 3 ) were performed using XRF and ICPMS on twenty of these samples at the National Geophysical Research
Institute, Hyderabad. A sample of Mahabaleshwar Flow (MB81\#1 of J.J. Mahoney collection) was also included in these analyses for the sake of comparison. XRF measurements were carried out using Philips PW 1400 model microprocessorcontrolled sequential X-ray fluorescence spectrometer following Govil (1985). Measurement of major and minor elements were found to be reproducible within $\pm 1 \%$. The trace elements and REE were determined using ICP-MS (Plasma Quad, PQ1). Japanese basalt standard (JB) was used as a reference. Details of the various procedures adopted are discussed in Balaram et al (1995, 1996). The trace element and REE data were found to be reproducible with precision better than $\pm 7 \%$ in the standards. U, Th and $\mathrm{K}$ were measured by gamma ray spectrometry using a hyperpure germanium detector having a relative efficiency of $25 \%$, located in a low background $10 \mathrm{~cm}$ thick lead shield. The concentration of $\mathrm{U}$ and $\mathrm{Th}$, given in table 4 , are based on the characteristic gamma ray energies of their daughter radionuclides $\left({ }^{214} \mathrm{Bi}\right.$ and ${ }^{208} \mathrm{Tl}$ respectively), assuming a secular equilibrium. Basalt 107 ( $\mathrm{U}=5.69 \mathrm{ppm}$, Th $=14.5 \mathrm{ppm}$ and $\mathrm{K}=2.63 \%$ ) in which the natural series is known to be in equilibrium was used as a standard.

Measurements of magnetic polarity were made on oriented hand specimens collected during June 1994 and drill core samples collected during 1995 using a Schonstedt spinner magnetometer (U.S.A.). Measurements were made on 5 to 15 samples of each oriented core (or specimen) and the average values are given in table 5 . After the measurement of Natural Remanent Magnetisation (NRM), the samples were subjected to thermal and/or alternate field demagnetisation (AFD) and the magnetic field was measured at several stages of demagnetisation.

\section{Results and discussions}

The results of analyses based on INAA are given in table 2 and those determined with XRF and ICPMS are given in table 3 . The precision of measurements for each element is given in these tables. In general, there is an agreement between the INAA, XRF and ICP-MS results although some values lie outside the expected range of errors. A similar situation exists for $\mathrm{U}, \mathrm{Th}$ and $\mathrm{K}$ concentrations measured by gamma ray spectrometry and other techniques. The dispersion may be due to several reasons such as weathering, alteration, sample inhomogeneity, use of different standards in different analyses as well as due to genuine variation in samples taken from different locations of the flows. Sample \#32 (Flow 3), published earlier (Bhandari et al 1996) appeared heavily weathered 
Table 4. Concentration of $U$, Th and $K$ determined by $\gamma$-ray spectrometry ${ }^{1}$.

\begin{tabular}{clccccc}
\hline Flow \# & Sample & $\mathrm{U}(\mathrm{ppm})$ & $\mathrm{Th}(\mathrm{ppm})$ & $\mathrm{K}(\mathrm{wt} \%)$ & $\mathrm{Th} / \mathrm{U}$ & $\mathrm{K} / \mathrm{U}$ \\
\hline F-9 & AJ 6-8 & 0.29 & 1.54 & 0.09 & 5.3 & 3103 \\
\hline F-7 & AJ 9-2 & 1.61 & 7.29 & 1.29 & 4.5 & 8012 \\
\hline F-6 & AJ 8-4 & 2.56 & 10.9 & 1.20 & 4.2 & 4687 \\
\hline F-5 & AJ 10-13 & 1.66 & 7.65 & 1.02 & 4.8 & 7692 \\
\hline F-5 & 4A & 1.69 & 8.23 & 1.30 & 4.6 & 6144 \\
\hline F-4 & AJ 4-5 & 1.57 & 6.24 & 0.83 & 3.9 & 5286 \\
\hline F-3 & AJ 3-10 & 0.87 & 3.84 & 0.86 & 4.4 & 9885 \\
\hline F-3 & AJ 2-14 & 0.92 & 4.29 & 0.97 & 4.6 & 10543 \\
\hline F-2 & AJ 1-10 & 1.84 & 7.74 & 1.42 & 4.2 & 7717 \\
\hline F-1 & AJ 11-13 & 1.16 & 4.32 & 1.43 & 3.7 & 12327 \\
\hline
\end{tabular}

${ }^{1} \mathrm{U}$ and Th concentrations were estimated via their daughter radionuclides assuming secular equilibrium of the radioactive series.

when examined petrographically and its low concentration of $\mathrm{Ba}, \mathrm{Na}, \mathrm{Cr}, \mathrm{Ni}$ etc may be due to this reason. Weathering can also lower concentration of elements like iron and sodium. Lead concentrations in different samples were also found to lie in a large range. In neutron activation analysis, the statistical errors due to counting are low as indicated in table 2 but values of certain elements like $\mathrm{Tb}$, $\mathrm{Gd}$, and $\mathrm{Zn}$ have interferences from high concentrations of elements giving strong gamma peaks in the neighbourhood of their gamma ray lines. $\mathrm{K}$ and $\mathrm{Na}$ in some samples could not be determined to a good accuracy because of significant decay before they could be counted. In spite of these uncertainties, various flows can be distinguished based on characteristic trace element concentrations and ratios as discussed later and the precision or reproducibility does not affect the arguments developed below. In this discussion we either use mean values of different analyses or those considered to be the most reliable, based on considerations of errors of measurements and interferences as discussed above.

\section{Chemical stratigraphy}

The Anjar flows have high amount of $\mathrm{Fe}_{2} \mathrm{O}_{3}$ (12.18 $-16.7 \%)$ and $\mathrm{TiO}_{2}(1.56-4.0 \%)$ which is similar to that generally found in some other Deccan basalts. Except for the upper-most flow (F9) in which $\mathrm{TiO}_{2}$ is $\sim 1.58 \%$, the concentration in all other flows is $\geq 3 \%$. These flows, except for F-3 and F-4, have high $\mathrm{Al}_{2} \mathrm{O}_{3}$ (14.64-17.03 \%). Therefore, they can be classified as high alumina basalts. The most striking feature is that the $\mathrm{SiO}_{2}$ content, with the exceptions of F-4, F-6 and F-8, range between 45.11 and $46.14 \%$, similar to that in alkali basalts. In comparison, F-4, F-6 and F-8 have relatively high $\mathrm{SiO}_{2}$ content (49.35-52.37\%). Similarly the $\mathrm{K}_{2} \mathrm{O}, \mathrm{Rb}$ and $\mathrm{Ba}$ are also enriched in Anjar flows as compared to the flows of Mahabaleshwar and Narmada region (Mahoney 1988). The $\mathrm{mg}^{*}$ number $\left(\mathrm{Mg}^{2+} /\left(\mathrm{Mg}^{2+}+\mathrm{Fe}^{2+}\right)\right)$, is low (0.45 to 0.52$)$ as shown in table 3 , in comparison to the other Deccan flows (e.g. MB81\#1 =0.58). The values indicate that the Anjar basalts are relatively more evolved compared to the primitive members of the Deccan, which have $\mathrm{mg}^{*}=0.7$. Flows 1,2 and 3 cluster in one group $\left(\mathrm{mg}^{*}=0.5\right)$, and $4,5,6$ fall in another group $\left(\mathrm{mg}^{*}=0.46\right)$. The remaining flows 7,8 and 9, have distinct values and do not fall in a group, thus their $\mathrm{mg}^{*}$ suggests change in magma composition. The REE patterns for various flows are shown in figure 2. Flow 9 is distinctly different from other flows and is similar to the least contaminated Ambenali type of basalts (Cox and Hawkesworth 1985; Mahoney 1988; Sano and Fujii 1996). The REE pattern of F9 is flatter and more depleted in LREE compared to Ambenali, indicating that it may represent even less contaminated magma. All other basalts have a high enrichment of LREE.

The Deccan basalts of the Western Ghats have been classified into several formations based on variation of some elements and elemental ratios e.g. $\mathrm{Sr}, \mathrm{Ba}, \mathrm{Rb}, \mathrm{Zr} / \mathrm{Nb}, \mathrm{Ba} / \mathrm{Y}$, and $\mathrm{TiO}_{2}$ (e.g. Devey and Lightfoot 1986; Beane et al 1986; Lightfoot et al 1990). These criteria are reproduced in table 6(a) and we can use them to classify Anjar flows. It may be noted that concentrations of some of these elements like $\mathrm{Rb}$ and $\mathrm{Ba}$, however, are known to change as a result of weathering and alteration, whereas others like $\mathrm{Zr}$ and $\mathrm{Nb}$ are not much affected and therefore are considered more diagnos- 
Table 5. Measurements of D and I of NRM and after thermal or AF demagnetisation and their comparison with measurements made at IPGP (Hofmann 1997).

\begin{tabular}{|c|c|c|c|c|c|c|c|}
\hline \multirow[t]{2}{*}{ Flow } & \multirow[t]{2}{*}{ Sample codes } & \multicolumn{2}{|c|}{$\mathrm{PRL}^{1}$} & \multicolumn{2}{|c|}{ IPGP } & \multirow{2}{*}{$\begin{array}{l}\text { Inferred } \\
\text { Polarity }\end{array}$} & \multirow[t]{2}{*}{ Adopted Age (Ma) } \\
\hline & & $\mathrm{D}$ & I & $\mathrm{D}$ & I & & \\
\hline \multirow[t]{3}{*}{ F-9 } & F7 & 150.50 & 62.0 & & & Reverse & 61.6 \\
\hline & & 150.46 & $46.38^{*}$ & & & & \\
\hline & AJ6 & 127.74 & 66.12 & 149 & 41.8 & & \\
\hline \multirow[t]{2}{*}{ F-8 } & F-6H.S. & 3.0 & 18.0 & & & Reverse & 64.8 \\
\hline & & 131.91 & $58.63^{*}$ & & & & \\
\hline F-7 & AJ9 & 356.45 & 18.04 & & & $\begin{array}{l}\text { Secondary vis- } \\
\text { cous component }\end{array}$ & \\
\hline F-6 & AJ 8 & 116.8 & 74.25 & 159.2 & 50.9 & Reverse & 65.1 \\
\hline \multirow[t]{2}{*}{ F-6 } & F 5B & 144.25 & 39.44 & & & Reverse & \\
\hline & & 146.6 & $17.4^{*}$ & & & & \\
\hline \multirow[t]{4}{*}{ F-5 } & $\mathrm{F}-4 \mathrm{~A}^{\prime}$ & 33.59 & 36.30 & & & Normal & \\
\hline & & 349.0 & $-38.55^{*}$ & & & & \\
\hline & $\mathrm{F} 4$ & 360.02 & -37.71 & & & & \\
\hline & & 348.97 & $-38.55^{*}$ & & & & \\
\hline \multirow[t]{2}{*}{ F-5 } & AJ10 & 338.04 & -20.4 & & & Normal & \\
\hline & & & & 343.6 & -30.6 & & \\
\hline \multirow[t]{2}{*}{$\mathrm{F}-4$} & AJ4 & 148.01 & 51.51 & & & Reverse & 65.4 \\
\hline & & 155.80 & 21.67 & 164.7 & 18.1 & & \\
\hline \multirow[t]{2}{*}{ F-3 } & F3\#32 & 337.8 & -31.89 & & & Normal & 65.1 \\
\hline & & 344.65 & -41.52 & & & & \\
\hline \multirow[t]{2}{*}{ F-3 } & AJ2 & 332.72 & -32.05 & 326.6 & -55.8 & Normal & \\
\hline & & 326.0 & -48.69 & 156.5 & 66.2 & & \\
\hline \multirow[t]{2}{*}{$\mathrm{F}-3$} & AJ3 & 349.18 & -4.51 & 353.7 & -47.8 & Normal & \\
\hline & & 311.12 & -47.24 & 142.3 & 32.9 & & \\
\hline \multirow[t]{5}{*}{$\mathrm{F}-2$} & AJ 1 & 316.75 & -12.05 & & & Normal & 66.6 \\
\hline & & 308.94 & -17.76 & 309.7 & -24.0 & & \\
\hline & $\mathrm{F} 2$ & 317.94 & 32.94 & & & & \\
\hline & & 331.52 & $-65.46^{*}$ & & & & \\
\hline & F1 & \multicolumn{2}{|c|}{$299.87-42.53$} & & & & \\
\hline F-1 & & 310.0 & $-33.35^{*}$ & & & & \\
\hline F-1 & AJ11 & $\begin{array}{c}352.14 \\
315.9\end{array}$ & $\begin{array}{c}19.65 \\
7.57\end{array}$ & 322.5 & -2.9 & $\begin{array}{l}\text { Secondary vis- } \\
\text { cous component }\end{array}$ & 67.8 \\
\hline
\end{tabular}

${ }^{1}$ The results after Alternate Field Demagnetisation (AFD) with 500 Oe or thermal demagnetisation at $550^{\circ} \mathrm{C}\left({ }^{*}\right)$. D: Declination, I: inclination

2 Adopted based on data given in table 1 and figure 4 . 

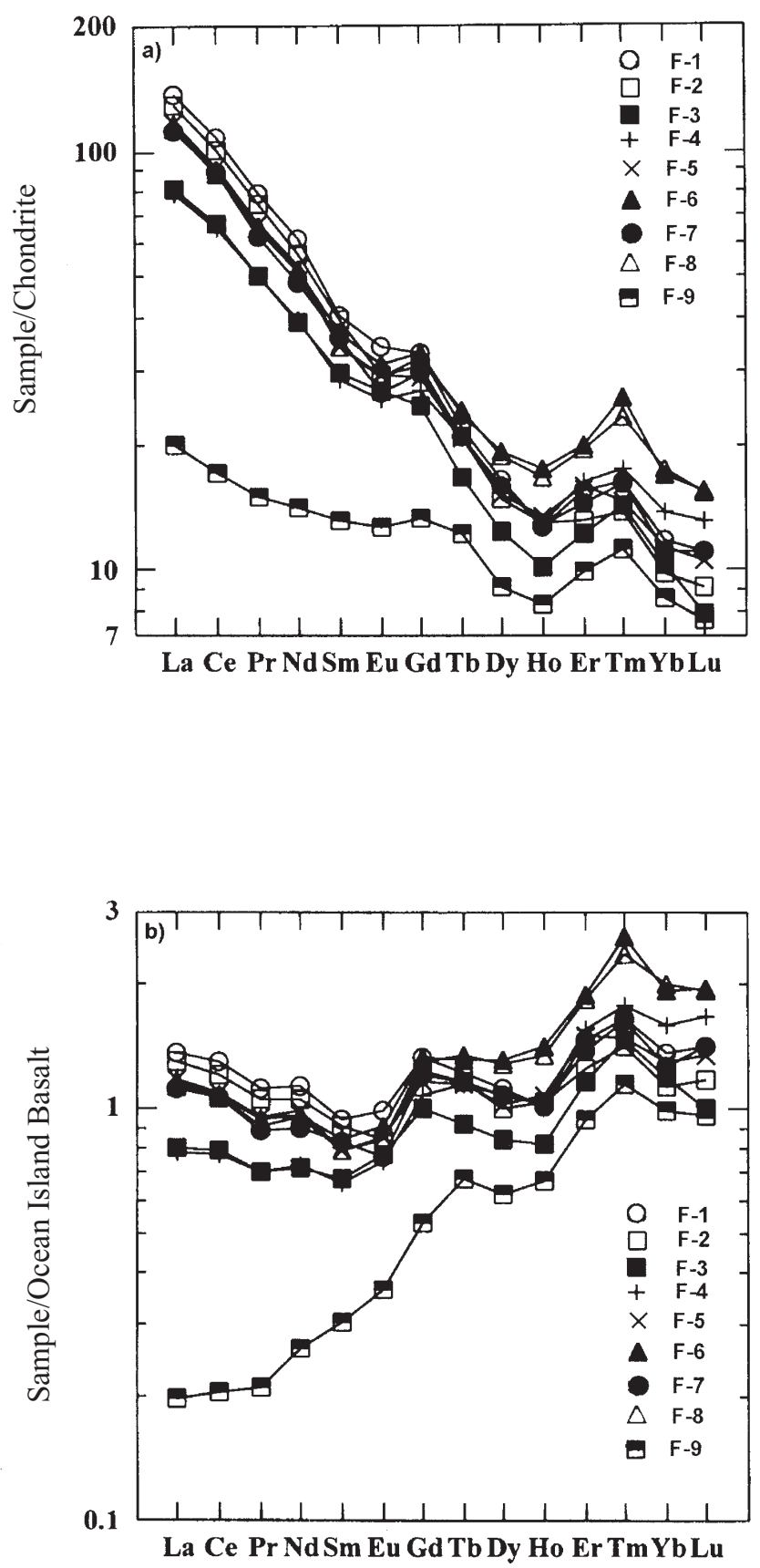

Figure 2. Typical Rare Earth Element (REE) patterns of each of the Anjar flows (a) normalized to chondrite and (b) Ocean Island Basalts (OIB).

tic for classification. The average concentrations of these elements in various Anjar flows are given in table 6(b). Comparison of these data with table 6(a) shows that F-9 is similar to the Ambenali type basalts whereas the other flows have no similarity to any of the Western Ghat flows. These observations suggest that the Anjar flows, except F9, are different from the typical Deccan flows. Measurement of isotopic ratio $\left({ }^{87} \mathrm{Sr} /{ }^{86} \mathrm{Sr}\right)$ in Anjar flows, which can provide additional confirmation of this conclusion, is in progress.
The concentration of $\mathrm{U}$, Th and $\mathrm{K}$, particularly the ratio $\mathrm{Th} / \mathrm{U}$ and $\mathrm{K} / \mathrm{U}$ can also be used to distinguish different basalts. It is clear from table 4 that the sample F9 and F1 have distinctly different $\mathrm{Th} / \mathrm{U}$ and $\mathrm{K} / \mathrm{U}$ whereas all the others fall within a narrow field.

Iridium is usually found to be low in the Deccan tholeiites, varying between 3 and 30pg/g (Orth et al 1990). However, we find that the iridium values in Anjar flows range between 2 and $178 \mathrm{pg} / \mathrm{g}$ (table 2). Surprisingly the flows 3 and 4, between which the iridium rich intratrappeans are found have low values of 2 and $50 \mathrm{pg} / \mathrm{g}$ respectively. The unusually high values of iridium $(30-178 \mathrm{pg} / \mathrm{g})$ in Anjar basalts, because of their small volume, however, do not substantially increase the contribution of the Deccan volcanism to the $\mathrm{K} / \mathrm{T}$ iridium enhancement and the high iridium inventory at KTB requires a bolide input (Alvarez et al 1980).

\section{Chronostratigraphy}

The various Anjar flows have been dated using the ${ }^{40} \mathrm{Ar}-{ }^{39} \mathrm{Ar}$ method at PRL as well as at IPGP, France. Earlier, Venkatesan et al (1996) reported the plateau age of F-3 $(65.2 \pm 0.6,64.9 \pm 0.8$ $\mathrm{Ma})$ and plateau like age of F-4 $(65.7 \pm 0.7 \mathrm{Ma})$ based on whole rock analyses. These ages put some constraint on the time span of deposition of the intertrappean-III lying in between F-3 and F-4, in which Ir anomaly has been reported (Bhandari et al 1995 and 1996). To understand the complete picture of Anjar sequence, we have compiled the available ages of the flows in table 1, based on the work of Venkatesan et al (1996), Hofmann (1997) and Venkatesan and Pande (personal communication). Considering multiple analyses by these groups, reliability and errors of measurements, each flow can be assigned a certain mean age. These assigned ages are also given in table 1 . In case of F-1, F$2, \mathrm{~F}-3$ and F-4, the weighted mean of plateau ages have been taken. In case of F-6, F-8 and F-9, the available integrated or estimated ages have been subjected to the weighted mean analyses. In this way, we have obtained the time span of the Anjar flow sequence, which ranges from $67.8 \pm 0.5$ to 61 $\pm 1.6 \mathrm{Ma}$. The uppermost flow F-9 did not yield an age plateau and is assigned an age of $61 \pm 1.6 \mathrm{Ma}$, being the most precise value available from the two laboratories. The flows F-8, F-6, F-4 and F-3 are similar in age and indistinguishable from the age of the K/T transition $(65.2 \pm 0.1 \mathrm{Ma}$; Izett et al 1991). However, the plateau ages of mineral separates and whole rock of flows F-2 and F-1 are older, $66.6 \pm$ $0.5 \mathrm{Ma}$ and $67.8 \pm 0.5 \mathrm{Ma}$ respectively. This range of ages fall close to the ages of the basal flows of 
Table 6. (a) Discrimination criteria of different formations of Deccan traps adopted by Lightfoot et al (1990). The Ba/Y and ${ }^{87} \mathrm{Sr} /{ }^{86} \mathrm{Sr}$ ratio criteria are taken from Devey and Lightfoot (1986).

\begin{tabular}{lccccccc}
\hline \multicolumn{1}{c}{ Formation } & $\begin{array}{c}\mathrm{Sr} \\
(\mathrm{ppm})\end{array}$ & $\begin{array}{c}\mathrm{Ba} \\
(\mathrm{ppm})\end{array}$ & $\begin{array}{c}\mathrm{Rb} \\
(\mathrm{ppm})\end{array}$ & $\mathrm{Zr} / \mathrm{Nb}$ & $\mathrm{Ba} / \mathrm{Y}$ & $\begin{array}{c}\mathrm{TiO}_{2} \\
(\mathrm{wt} \%)\end{array}$ & ${ }^{87} \mathrm{Sr} /{ }^{86} \mathrm{Sr}$ \\
\hline Mahabaleshwar & $>225$ & $>90$ & & $<13.0$ & 4 & $>2.00$ & $>0.705$ \\
Ambenali & $<240$ & $<100$ & $<8$ & $<11.0$ & $<3.5$ & $<2.70$ & $<0.705$ \\
Poladpur & & $>100$ & $>8$ & $>11.0$ & $>3.5$ & & $0.705-0.713$ \\
Bushe & $<185$ & $>100$ & $>15$ & $>17.0$ & & $<1.50$ & $>0.713$ \\
Panhala & $<200$ & $<100$ & $<10$ & $>12.5$ & & $<2.10$ & \\
Desar & $>230$ & $>150$ & $>15$ & $<12.5$ & & $<2.25$ & \\
Kolhapur & $>200$ & & & $<14.0$ & & $>2.25$ & \\
\hline
\end{tabular}

Table 6. (b) Average concentrations of some characteristic elements and elemental ratios in Anjar flows.

\begin{tabular}{clcccccc}
\hline Flow & Sample & $\begin{array}{c}\mathrm{Sr} \\
(\mathrm{ppm})\end{array}$ & $\begin{array}{c}\mathrm{Ba} \\
(\mathrm{ppm})\end{array}$ & $\begin{array}{c}\mathrm{Rb} \\
(\mathrm{ppm})\end{array}$ & $\mathrm{Zr} / \mathrm{Nb}$ & $\mathrm{Ba} / \mathrm{Y}$ & $\begin{array}{c}\mathrm{TiO}_{2} \\
(\mathrm{wt} \%)\end{array}$ \\
\hline F-9 & KP-7 & 165.4 & 109.5 & 4.3 & 10.78 & 3.05 & 1.58 \\
F-8 & KP-6 & 1838.9 & 564.25 & 66.63 & 6.84 & 11.60 & 3.15 \\
F-7 & AJ 9-12 & 343.35 & 269.56 & 43.71 & 6.74 & 6.71 & 3.65 \\
F-6 & KP-5 & 218.4 & 316.5 & 74.7 & 7.38 & 6.65 & 3.21 \\
F-5 & 4 A & 359.9 & 306.11 & 45.7 & 4.82 & 7.7 & 3.9 \\
F-4 & AJ 4-1 & 239.73 & 244.0 & 38.33 & 10.62 & 6.55 & 2.82 \\
F-3 & AJ 2-3 & 7430.0 & 259.4 & 19.2 & 5.08 & 9.0 & 3.77 \\
F-2 & AJ 1-15 & 403.62 & 332.61 & 41.89 & 4.78 & 9.58 & 3.95 \\
F-1 & AJ 11-2 & 434.04 & 323.0 & 41.08 & 4.83 & 948 & 3.77 \\
\hline
\end{tabular}

the Western Ghats ( Venkatesan and Pande 1996). This observation clearly indicates that the Deccan volcanism started before the $\mathrm{K} / \mathrm{T}$ transition. We discuss this point further in the next section while considering the palaeomagnetic measurements.

\section{Magnetic stratigraphy}

The results of measurements of natural remanent magnetisation (NRM) are given in table 5. Many of the samples show a viscous component, which can be resolved by AFD (alternate field demagnetisation) or thermal treatment. The deduced declination and inclination for various flows are given in table 5. If we make a simplistic assumption that any viscous component present should acquire the present day field at the site, then such samples should not be considered for deducing the primary magnetisation acquired at the time of solidification of the flows. The inferred polarity given in table 5 excludes such samples. In some cases, it is difficult to erase the secondary component totally by thermal or AF demagnetisation, but there are samples where secondary imprints could be com- pletely erased and direction of primary magnetisation measured. We show some typical examples of AFD behavior of Flows 1, 2, 3 and 4 in vectorial projections (figure 3). Replicate measurements of Flow 1, 2 and 3 gave consistent results showing normal polarity whereas Flow 4 shows reversed polarity. Hofmann (1997) has discussed the complexity of magnetic records in various flows and problems in deducing the direction of primary magnetization. In the flows above the iridium layer (except for F-5), the primary direction of magnetisation could be deduced with confidence. These results are also given in table 5 for comparison. First we compare our results with that of Hofmann (1997) since many of the measurements were made on the same core samples. There is a general agreement between the two data sets obtained at PRL and IPGP as far as the apparent direction of magnetization is concerned. In case of Flow 1 (AJ11) and Flow 7 (AJ9), Hofmann (1997) finds that magnetic records are too complex to determine the direction of primary polarity whereas in the case of Flows 2 and 3 , she has reported a weak reversed primary field. These conclusions do not fully agree with our work and in view of the strong secondary imprint, these results require further confirmation. 

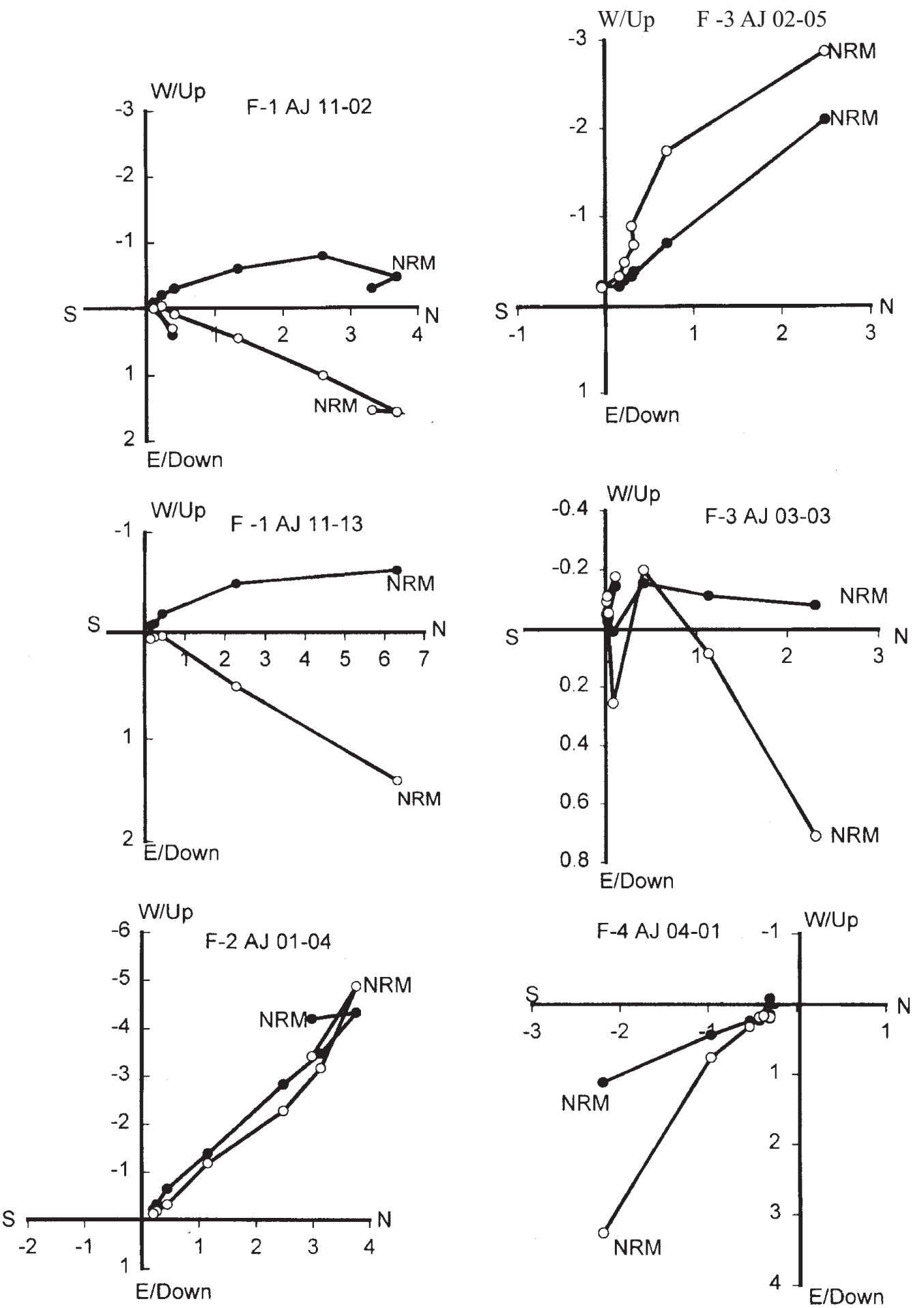

Figure 3. Typical examples of Alternate Field Demagnetisation (AFD) behaviour for Flows 1, 2, 3 and 4. The vectorial diagrams (Zijerveldt plots) show projections on vertical and horizontal planes as a function of AFD field strength. The axes are in $\left(\mathrm{x} 10^{-3}\right)$ gauss/g. 


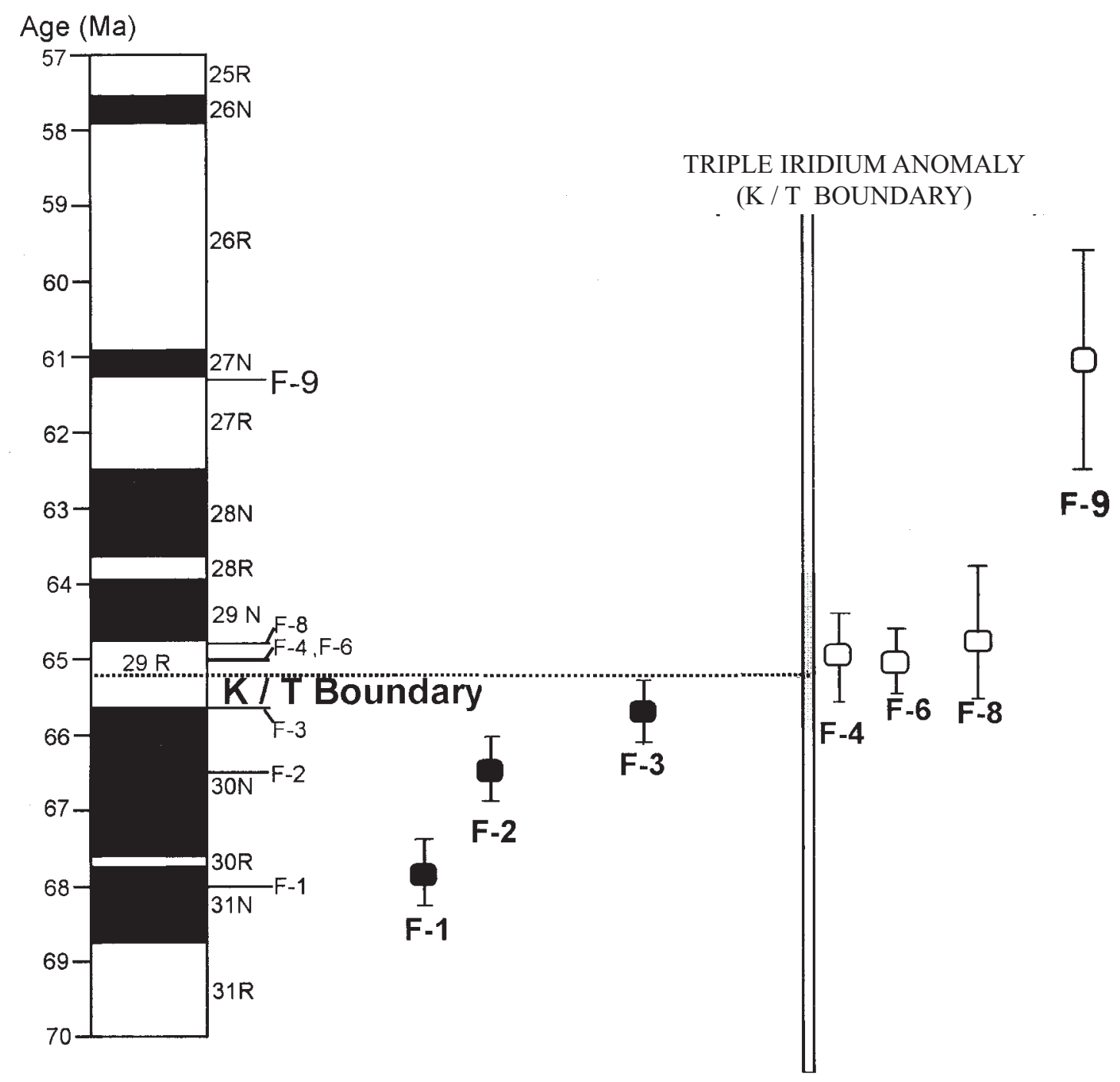

Figure 4. Magnetic and geochronological stratigraphy based on assigned ages, (see text) of various Anjar Flows. The magnetic chrons are taken from Cande and Kent (1995). F-5 and F-7 are not included because their ages are not known. The location of $\mathrm{K} / \mathrm{T}$ boundary, in the third intertrappean bed where triple iridium anomaly has been found is marked.

In summary, considering only the reliable measurements, we find that the lower flows $(1,2$, and $3)$ are normal and the upper flows $(4,6,8$ and 9$)$ are reversed. It is possible that the flows 5 and 7 , which were collected from the western fringe of the region, close to a cluster of dykes, have their magnetic polarity influenced by thermal effects associated with dyke formation. This uncertainty must be kept in mind in the following discussion.

Combining the magnetic data with the geochronological framework, we find that Flows 4, 6 , and 8 can be placed in Reversed chron 29R. The lower flows (F2 and 3) will probably lie in chron $30 \mathrm{~N}$ and F-1 probably in $31 \mathrm{~N}$ (figure 4 ). The age of Flow-9 is not reliable but it may belong to chron 28 or $27 \mathrm{R}$. For F-7 and F-5, the magnetic data and ages have not been obtained and we can not ascertain their position in the chronostratigraphic sequence. In spite of these uncertainties, the results on magneto- and chrono-stratigraphy confirm that the Anjar volcano-sedimentary sequence was not emplaced in a short period of time $(<1 \mathrm{Ma})$ but had an extended period of formation as proposed by Venkatesan et al (1993) and Venkatesan and Pande (1996).

Traditionally, the $\mathrm{K} / \mathrm{T}$ boundary is believed to fall in Reverse chron 29R although Lerbekmo and Sweet (1994) have reported a short $(\sim 45 \mathrm{ka})$ normal polarity chron, just at the KTB within 29R. The age bracket (68-61 Ma) of Anjar flows is the same as that of Mahabaleshwar sequence in Western Ghats, which were also dated in our laboratory yielding identical time span (67 to $61 \mathrm{Ma}$; Venkatesan et al 1993). The magnetic polarity of all the Mahabaleshwar flows is reversed (Khadri et al 1988) whereas the Anjar flows show at least one Normal-Reverse sequence (table 5, figure 4). The upper Anjar flows above the iridium layer, 
(except F-5 and F-7, where the results are ambiguous), therefore can possibly be correlated with the Mahabaleshwar sequence from the point of view of their magnetic polarity. However, the lower flows have the same age as the basal part of the Mahabaleshwar sequence (Venkatesan et al 1993) but show opposite polarity. This disagreement requires further study to be resolved.

The change from normal to reverse polarity seems to have occurred within IT-III, where the KTB has been identified. However, the data for the upper flows are not sufficiently reliable for us to conclude that the impact, which presumably gave rise to the iridium rich horizons in IT-III, was also responsible for the polarity change during the $\mathrm{K} / \mathrm{T}$ transition. Careful and high resolution study of intertrappean sediments, which have very mild magnetic field, is required to address this point.

\section{Geochemical nature of the magma}

Certain chemical criteria have been developed to characterize the parent magmatic fluids from which basaltic lavas originate and to distinguish between different basalt types. Some of the well established criteria are based on $\mathrm{TiO}_{2}$ content, $\left(\mathrm{Na}_{2} \mathrm{O}+\mathrm{K}_{2} \mathrm{O}-\right.$ $\left.\mathrm{SiO}_{2}\right), \mathrm{MnO}_{2}-\mathrm{TiO}_{2}-\mathrm{P}_{2} \mathrm{O}_{5}, \mathrm{TiO}_{2}-\mathrm{Zr} / \mathrm{P}_{2} \mathrm{O}_{5}$, $\mathrm{Nb} / \mathrm{Y}-\mathrm{Zr} / \mathrm{P}_{2} \mathrm{O}_{5}$ and $\mathrm{Zr} / \mathrm{Y}-\mathrm{Zr}$ discrimination diagrams. In order to use these criteria, we have plotted the major and trace element data in various discriminating diagrams (figures 5, 6, 7, 8) discussed below.

The geochemical data on Anjar basalts reveal that all the flows (except F-9) have an alkaline nature. On the total alkali- $\mathrm{SiO}_{2}$ diagram (figure $5 \mathrm{a})$, the Flows 1, 2, 3, 5 and 7 fall above the discriminating line between subalkalic and alkali fields whereas Flows 4, 6 and 8 lie close to the demarcating line. Flow F-9 lies in the subalkalic region. This is further supported by $\mathrm{Zr} / \mathrm{TiO}_{2}-\mathrm{Nb} / \mathrm{Y}$ diagram (figure 5b) where all flows except F-4 and F-9 lie in the alkali basalt field. F-4 lies close to the transition zone between tholeiites and alkali basalts. That the high concentration of alkali elements is not due to crustal contamination or subsequent alteration of basalt can be confirmed from the $\mathrm{TiO}_{2}-\mathrm{Zr} / \mathrm{P}_{2} \mathrm{O}_{5}\left(\mathrm{x} 10^{4}\right)$ and $\mathrm{Nb} / \mathrm{Y}-\mathrm{Zr} / \mathrm{P}_{2} \mathrm{O}_{5}\left(\mathrm{x} 10^{4}\right)$ diagrams of Floyd and Winchester (1975). These plots, shown in figure 6(a) and 6(b), confirm that the magma which gave rise to the Anjar basalts, particularly F-1, 2, 3, 5 and 7 was alkaline, F-4, 6 and 8 was transitional while F-9 was subalkaline. This is also supported by high $\mathrm{Nb}$ concentration (and high $\mathrm{Nb} / \mathrm{Y}$ ) as given in table 3 , a criterion proposed by Winchester and Floyd (1977). Again, since $\mathrm{Th}, \mathrm{Yb}$ and $\mathrm{Ta}$ are highly incompatible elements, which can not be readily incorporated in
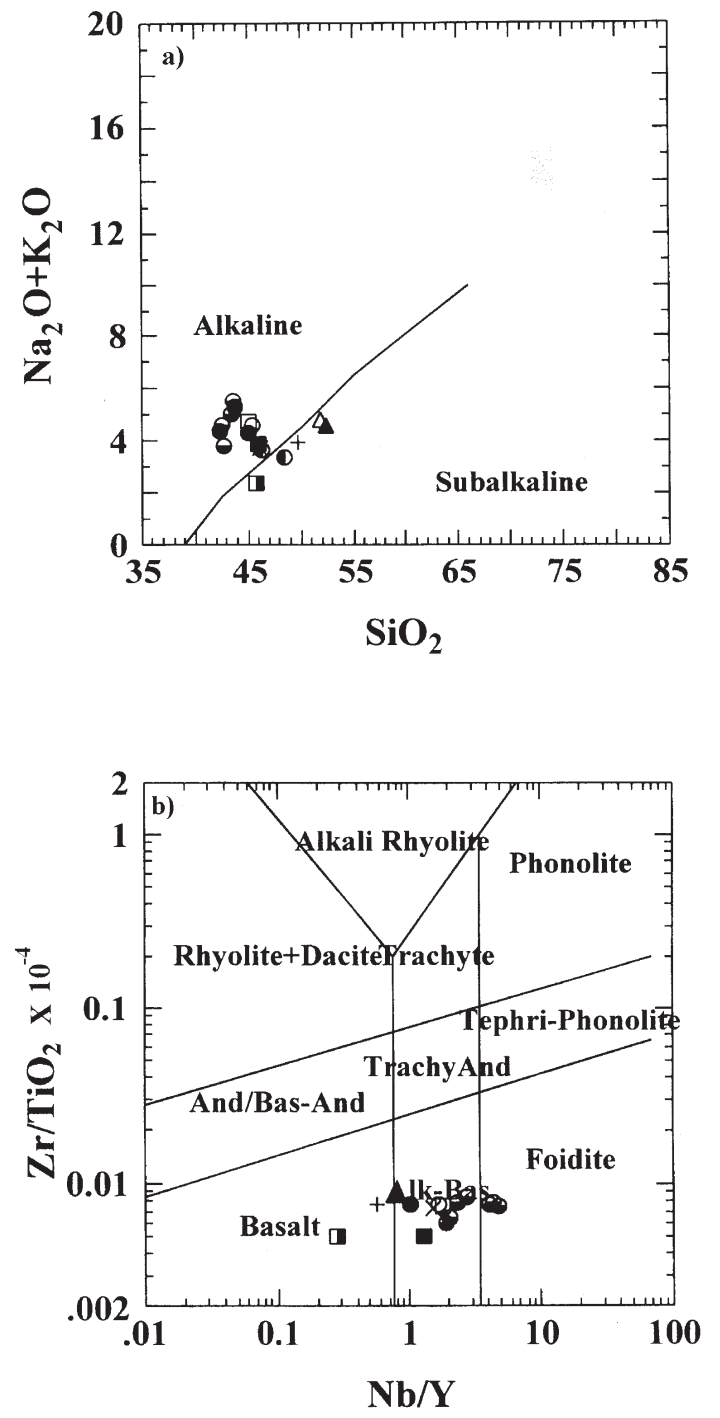

Figure 5. (a) The total alkali and silica (TAS) diagram i.e. $\mathrm{Na}_{2} \mathrm{O}+\mathrm{K}_{2} \mathrm{O}$ vs. $\mathrm{SiO}_{2}$. Flows $1,2,3,5$ and 7 fall in the field of alkaline basalts whereas Flows 4,6 and 8 fall near the demarcating line. The upper most flow F 9 falls within the subalkaline field. Data points of alkali basalts (half filled circles) from Bhujia hill, Kutch (Pande 1988) and tholeiites (half filled circles) from Saurashtra region (Shekhawat and Sharma 1996) are also shown for comparison (b). Data points of Anjar flows in $\mathrm{Nb} / \mathrm{Y}$ vs. $\mathrm{Zr} / \mathrm{TiO}_{2} \times 10^{-4}$ diagram.

the magma during its passage through the crust, $\mathrm{Th} / \mathrm{Yb}$ vs. $\mathrm{Ta} / \mathrm{Yb}$ diagram (figure 7 ) gives another criterion for crustal contamination (Pearce 1980). Based on all these criteria, we classify Anjar basalts (except F-9) as alkaline and F-9 as tholeiitic.

It is clear from figure 7 that all the Anjar flows plot in the enriched mantle source zone near the region of intraplate basalts, parallel to vector $\mathrm{W}$. The within-plate origin of Anjar flows is further confirmed by using the discrimination diagram of Pearce and Cann (1973) based on $\mathrm{Ti}-\mathrm{Zr}-\mathrm{Y}$, which they used to distinguish between ocean or continental flood basalts from other basalt types (figure 8a). We find that the Anjar flows, except F-9, plot 

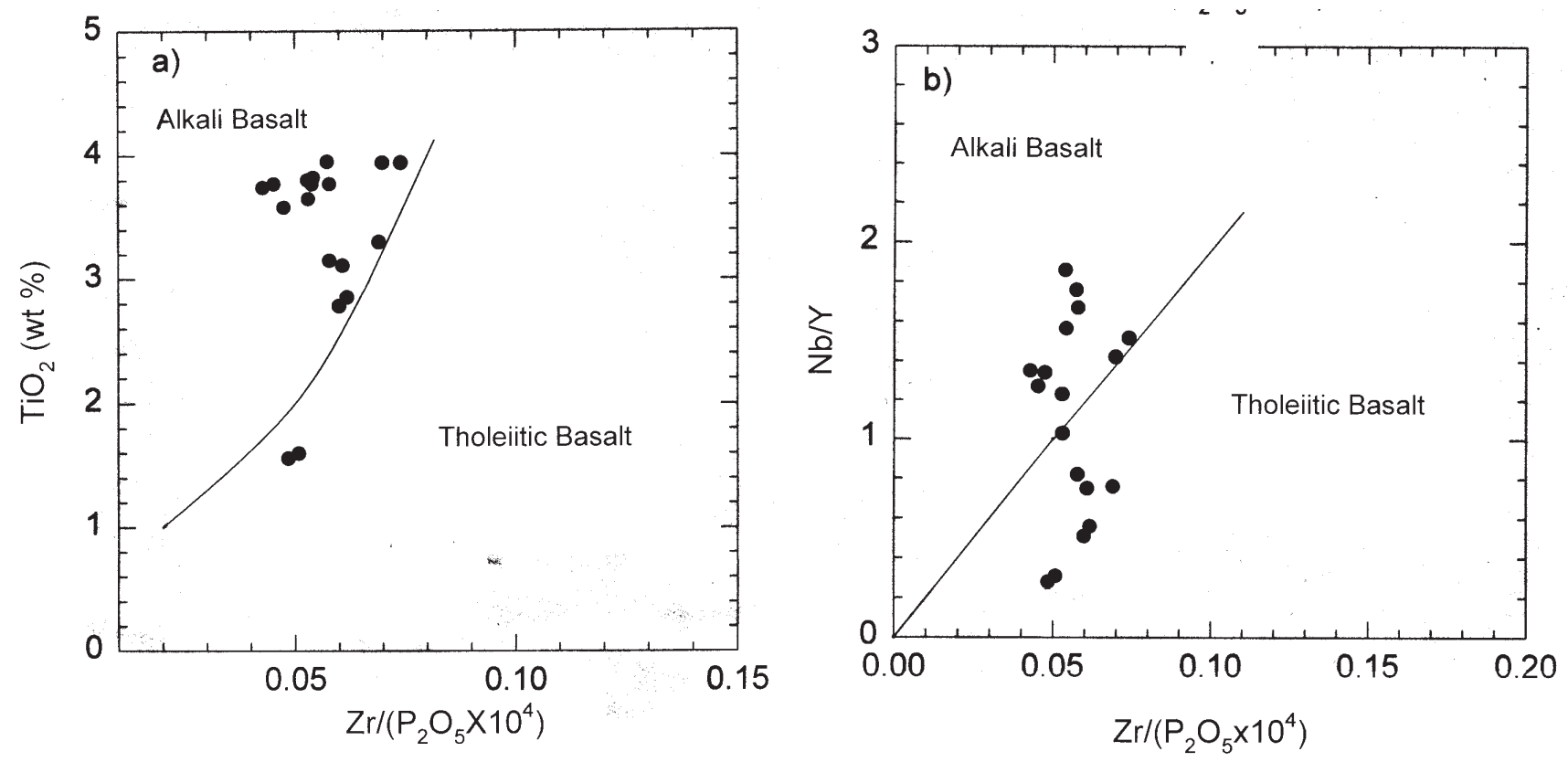

Figure 6. (a). Data points of Anjar flows in $\mathrm{TiO}_{2}$ vs. $\mathrm{Zr} / \mathrm{P}_{2} \mathrm{O}_{5} \times 10^{4}$ diagram; (b). Data points of Anjar flows in $\mathrm{Nb} / \mathrm{Y}$ vs. $\mathrm{Zr} / \mathrm{P}_{2} \mathrm{O}_{5} \times 10^{4}$ diagram.

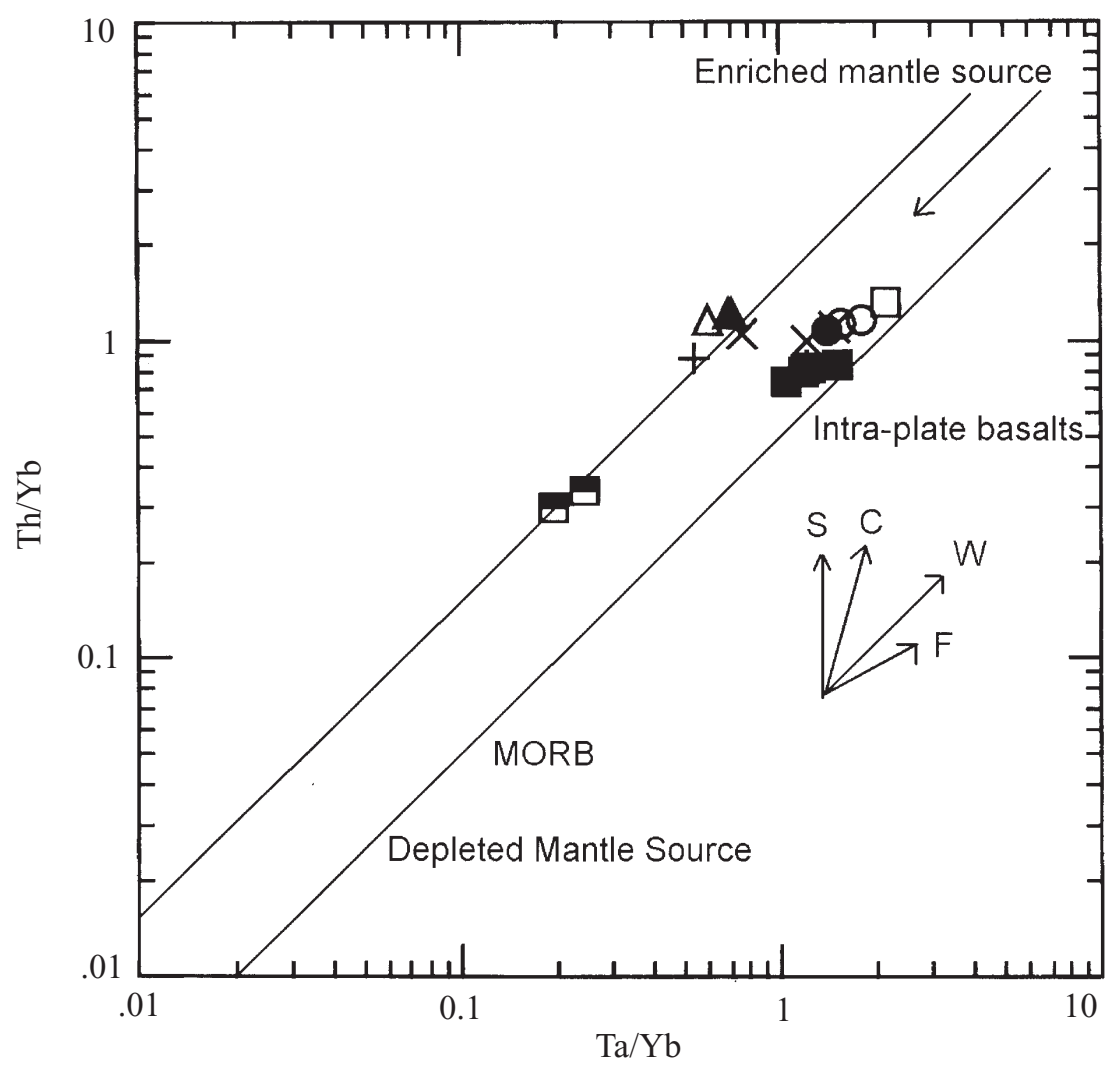

Figure 7. Th/Yb vs. Ta/Yb diagram of Pearce (1980). The Anjar flows plot within the enriched mantle zone. The vectors shown indicate the influence of subduction component (S), within plate enrichment (W), crustal contamination (C), and fractional crystallization $(\mathrm{F})$. 


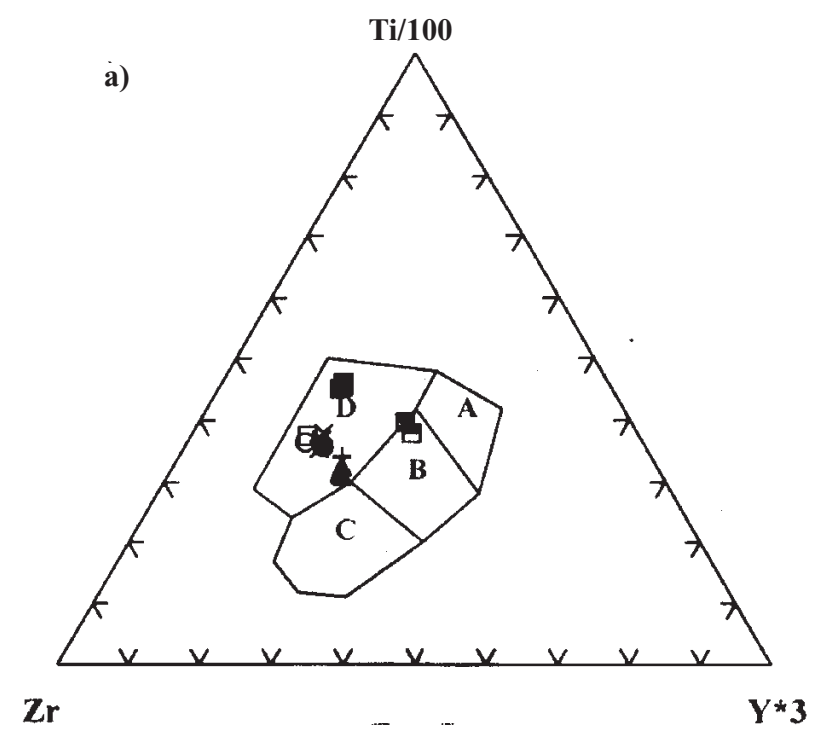

Figure 8(a). The discrimination diagram Ti-Zr-Y of Pearce and Cann (1973) showing that Anjar basalts lie within the within-Plate Basalt field [D].

within field D of within-plate basalts. The Zr/Y vs. Zr diagram of Pearce and Norry (1979) also confirms their within-plate origin (figure 8b).

The Ti - Cr plot (after Pearce et al 1975) shows that all the Anjar flows plot on the Ocean floor Basalt (OFB) field (figure 8c). This is further confirmed by the $\mathrm{Hf}-\mathrm{Th}-\mathrm{Nb} / 16$ (or $\mathrm{Ta}$ ) diagram of Wood (1980), that differentiates various types of basalts of oceanic environment from each other (figure 8d). It can be noted that the alkaline flows (F-1, 2, 3, 5 and 7) plot in the field of alkaline within-plate and the subalkaline flows F-4, F-6 and F-8 plot at the transition zone of E-MORB (enriched mid oceanic ridge basalt) and alkali within-plate field. On the other hand, F-9 plots in the E-MORB field. Meschde (1986) has suggested that the incompatible element $\mathrm{Nb}$ can be used to separate different types of ocean floor basalts and also distinguish different types (Enriched, Plume or Normal ) of MORBs. We reproduce this discrimination diagram in figure $8(\mathrm{e})$ from which we conclude that all the Anjar flows lie in within-plate alkali basalt field. The ocean island alkali basaltic nature of most of the Anjar flows is confirmed by the major element $\left(\mathrm{MnO}-\mathrm{P}_{2} \mathrm{O}_{5}-\mathrm{TiO}_{2}\right)$ discrimination diagram (figure 8f, after Mullen 1983).

Thus, based on all the major, minor and trace element data discussed above, we conclude that the Anjar flows have originated within plate region in oceanic environment i.e. they have not been generated at plate margins. Rather these have origin similar to Ocean Island Basalt (OIB). Furthermore, the OIB normalized pattern of REE is flat, supporting the OIB nature (figure $2 \mathrm{~b}$ ). In table 7 , we compare crucial trace elements like $\mathrm{Ba}, \mathrm{K}, \mathrm{Rb}$, $\mathrm{Sr}, \mathrm{Nb}$ and $\mathrm{K} / \mathrm{Ba}$ in different types of Anjar basalts

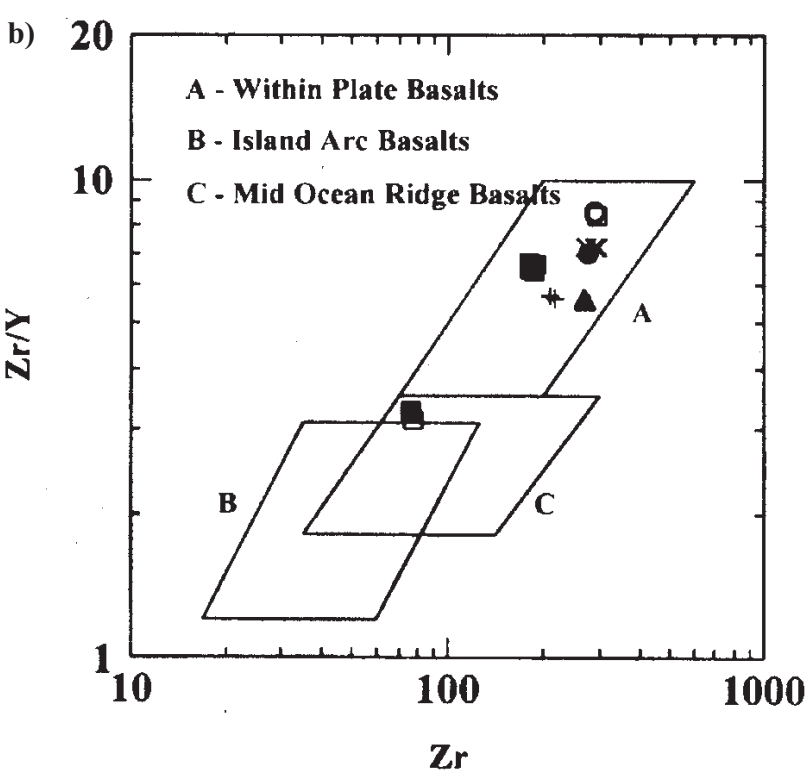

Figure 8(b). The discrimination diagram for basalts based upon $\mathrm{Zr}$ vs. $\mathrm{Zr} / \mathrm{Y}$ variation (after Pearce and Norry 1979). Anjar flows lie within the within-Plate Basalt field [A].

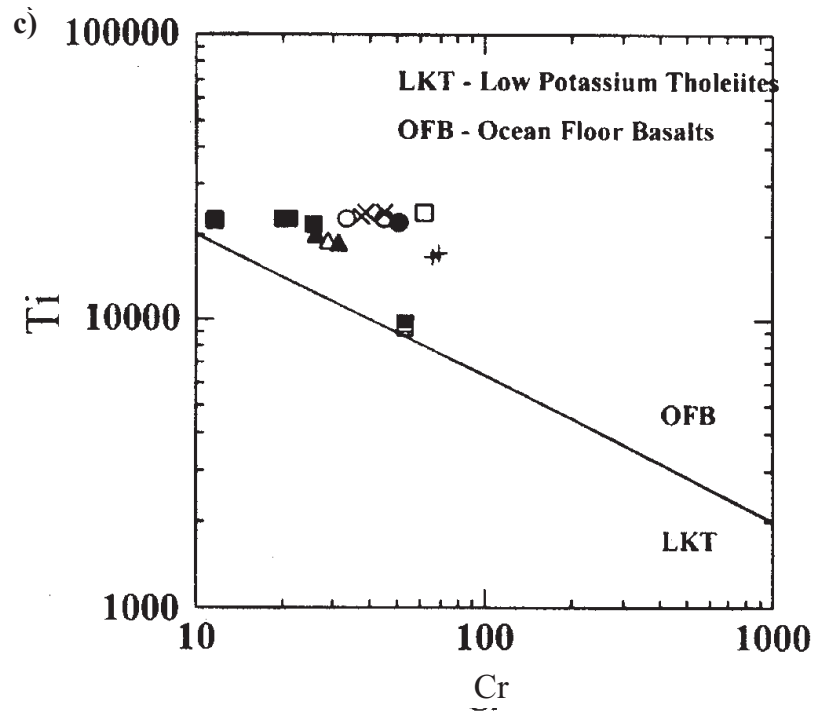

Figure 8(c). The Anjar basalt data points on the Cr vs. Ti discrimination diagram of Pearce et al (1975).

with MORB, OIT (Ocean Island tholeiites) and OIAB (Ocean island alkali basalts). These data as well as multi-element variation diagram i.e. spidergram (figure 9) also supports the conclusion that Anjar basalts (except F9) belong to OIAB group.

We use these data (tables 2, 3) to ascertain if there is any similarity between Anjar basalts and Réunion basalts, since the Réunion plume has been suggested as a source of Deccan volcanism (Morgan 1972, 1981). $\mathrm{Y} / \mathrm{Nb}$ vs. $\mathrm{Zr} / \mathrm{Nb}$ data plotted in figure 10 show that some of the Anjar basalts and Réunion basalts (Fisk et al 1988) overlap. The REE patterns of alkali basalts from Réunion Island 
Hf/3

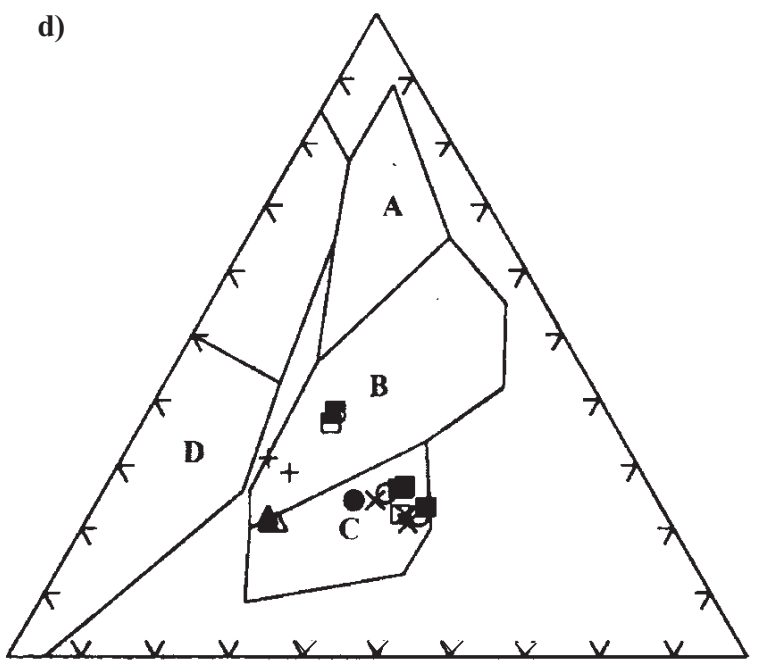

Th

Nb/16 f)

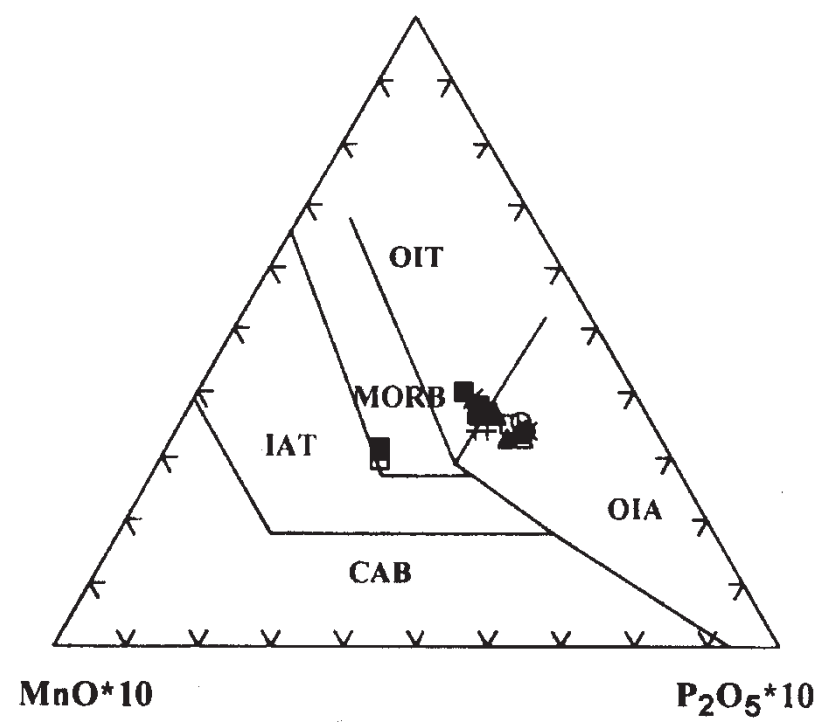

Figure 8(d). The Hf-Th-Nb/16 discrimination diagram of Wood (1980). The various fields are: [A] N type MORB; [B] E type MORB and within-plate tholeiites; [C] alkaline within-plate basalts; [D] volcanic-arc basalts. The Anjar basalts 1, 2, 3, 5 and 7 lie in alkaline within-plate region while F-4 and 9 in E-type MORB and within-plate tholeiites field. The flows 6 and 8 fall at the transition line of field $\mathrm{C}$ and $\mathrm{B}$.

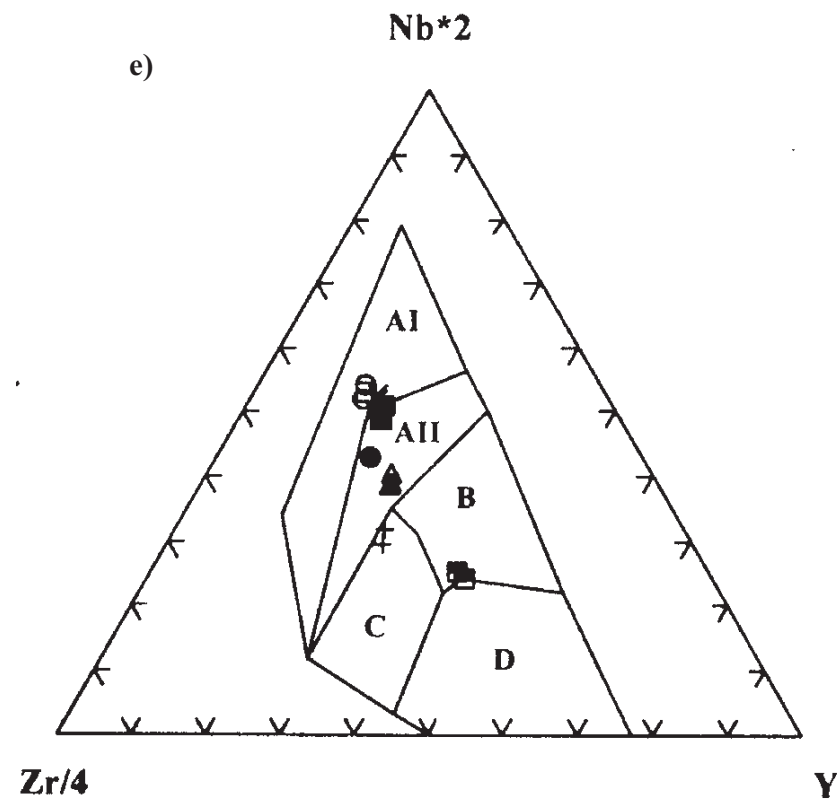

Figure 8(e). The Zr-Y-Nb discrimination diagram of Meschede (1986), the various fields: [AI] within-plate alkali basalts; [AII] within-plate alkali and within-plate tholeiites; [B] E-type MORB; [C] within- plate tholeiites and volcanicarc basalts; [D] N type MORB and volcanic-arc basalts. The flows 1, 2, 3, 5, 6 and 8 of Anjar fall in within-plate alkali basalt region. Flow-9 lies in E-MORB field. Flow 4 lies near the boundary of fields AII and C.
Figure $8(\mathrm{f})$. The $\mathrm{MnO}-\mathrm{TiO}_{2}-\mathrm{P}_{2} \mathrm{O}_{5}$ discrimination diagram of basalts and basaltic andesites (after Mullen 1983). The fields are: MORB; OIT: ocean island tholeiite or seamount tholeiite; OIA: ocean -island alkali basalt or seamount alkali basalt; IAT: island-arc tholeiite; CAB: calc-alkaline basalt. Typical flows of Anjar area are plotted. All except F-9 lies in OIA or at close to the boundary of OIA and OIT whereas F-9 falls within MORB field.

(Fisk et al 1988) are similar to that observed in Anjar basalts. $\mathrm{Sm} / \mathrm{Nd}$ and $\mathrm{Ba} / \mathrm{Nb}$ ratios have been used by Peng et al (1994) to compare Deccan and Réunion basalts. Following the same arguments, we find that most of the Anjar basalt data scatter close to the Réunion data (figure 11). This argument is not a strong evidence in favour of the Réunion origin of flows but only shows chemical similarities between the Réunion basalts with the Anjar traps. This aspect needs to be studied further by using various isotopic criteria. The uppermost flow F 9, however, plots away from Ambenali, although $\mathrm{Sm} / \mathrm{Nd}$ is similar. Isotopic systematics of $\mathrm{Pb}-\mathrm{Sr}-\mathrm{Nd}$ can confirm the true affinity of these basalts as has been done for the northeastern and southwestern flows of Deccan.

\section{Summary and conclusions}

The chemical, chronological and magnetic characteristics of the basalt sequence at Anjar are discussed and compared with the southwestern and northeastern flows. The results show that some of the Anjar basalts are alkaline and resemble ocean island alkali basalts in their major and trace element characteristics. The Anjar basalt sequence represents a rare section comprising alkali basalts capped by tholeiites. Similarities of some diagnostic trace element ratios with Réunion Island 
Table 7. Comparison of selected trace element abundances of Anjar flows ( except F-9) with MORB, ocean island tholeiites (OIT) and ocean island alkali basalts $(O I A B)$.

\begin{tabular}{ccccc}
\hline & MORB & OIT & OIAB & Anjar Basalts \\
\hline $\mathrm{K}_{2} \mathrm{O} \%$ & $<0.1-0.3$ & $0.2-1.0$ & $1-7$ & $0.94-1.68$ \\
$\mathrm{Ba}(\mathrm{ppm})$ & $5-50$ & $70-200$ & $200-1400$ & $237.5-564.3$ \\
$\mathrm{Sr}(\mathrm{ppm})$ & $90-200$ & $150-400$ & $400-4000$ & $222.2-1839$ \\
$\mathrm{Rb}(\mathrm{ppm})$ & $<5$ & $5-12$ & $15-400$ & $14.6-71$ \\
$\mathrm{Zr}(\mathrm{ppm})$ & $15-150$ & $100-300$ & $200-1000$ & $179.5-297$ \\
$\mathrm{Nb}(\mathrm{ppm})$ & $1-15$ & $5-25$ & $20-160$ & $18.8-64$ \\
$\mathrm{~K} / \mathrm{Ba}$ & $20-160$ & $25-40$ & $\sim 28$ & $24.5-46.7$ \\
\hline
\end{tabular}
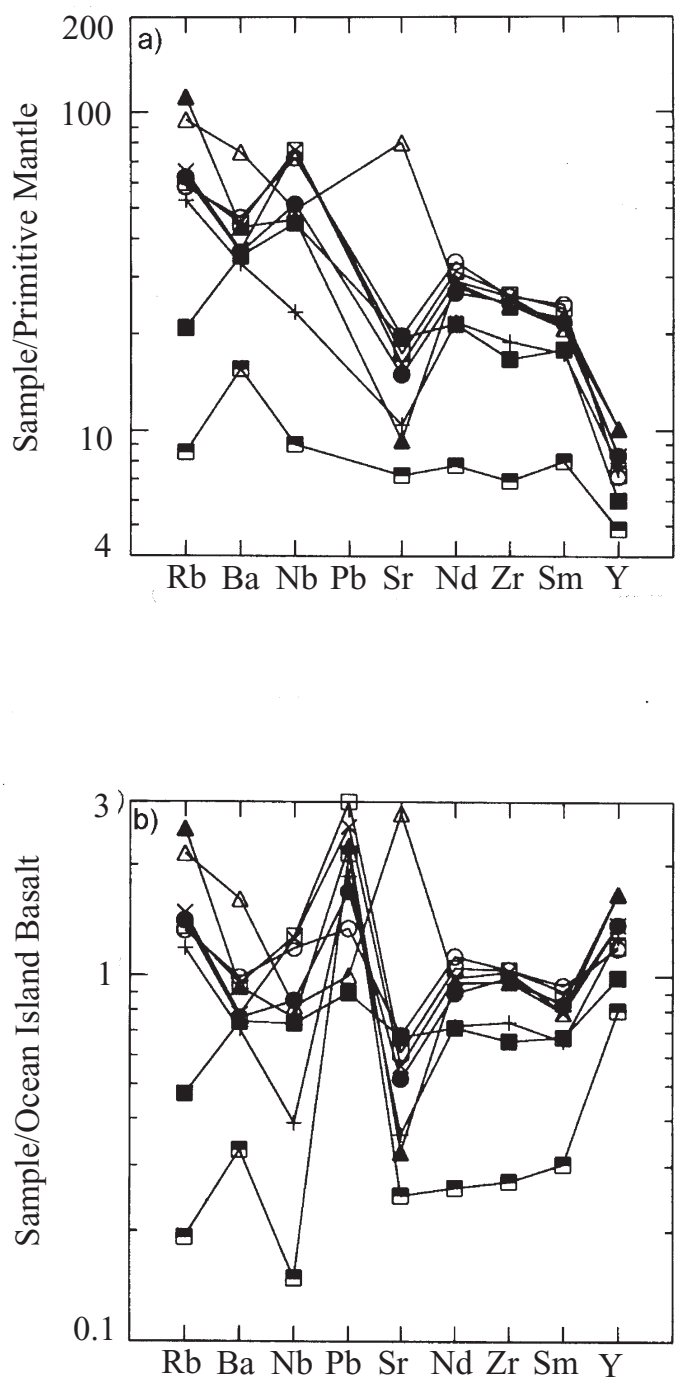

Figure 9. Typical multi element Spidergram for Anjar flows normalized to (a) Primitive mantle and (b) average Ocean Island Basalts.

basalts are consistent with their plume origin in the Réunion hot spot but these chemical arguments are not unique or strong enough to prove the Réunion plume origin of Deccan. The ages of Anjar basalts lie in the same range as the ages of southwest-

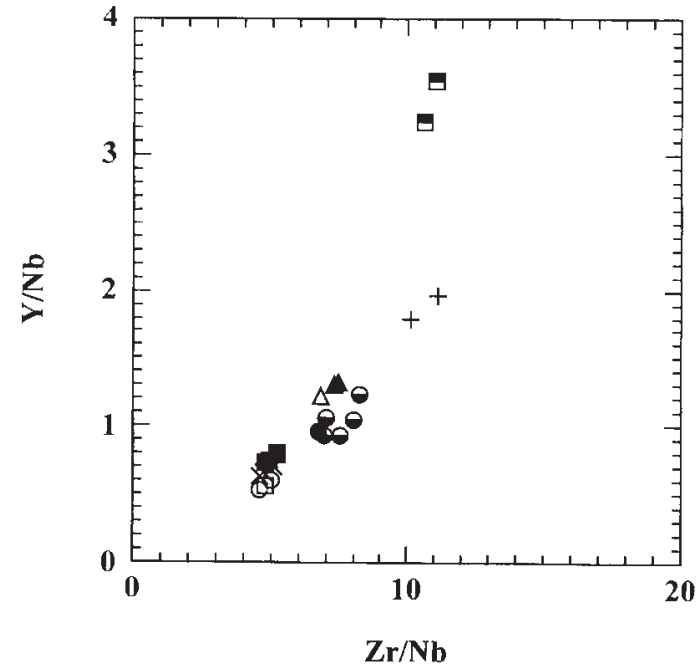

Figure 10. The variation of $\mathrm{Y} / \mathrm{Nb}$ and $\mathrm{Zr} / \mathrm{Nb}$ in the Anjar flows showing similarity to Réunion basalts (half filled circles, Fisk et al 1988).

ern and northeastern flows of Deccan Traps (68-61 $\mathrm{Ma}$ ) and they constitute a N-R and possibly a NR-N-R magnetic polarity sequence, similar to the northeastern flows (Sreenivasa Rao et al 1985). The upper most flow of Anjar (F 9) is similar in chemical composition to Ambenali basalts. Its REE pattern suggests that it is even less contaminated compared to the Ambenali group. This flow may have originated in a similar 'uncontaminated' magma pool; the possibility of lava flowing great distances (a few hundred $\mathrm{km}$ ) has been discussed by Peng et al (1998).

The iridium content of Anjar basalts is high; F-2 shows the highest value $(178 \mathrm{pg} / \mathrm{g})$ observed in Deccan Traps so far. However, since alkali basalts form only a small fraction of Deccan Traps, their contribution to the iridium inventory at $\mathrm{K} / \mathrm{T}$ boundary may be insignificant and its main source may be related to a bolide impact. In view of the high iridium content, dinosaur bearing intertrappeans, N$\mathrm{R}$ magnetic polarity sequence and wide age span, the Anjar volcano-sedimentary sequence appears 


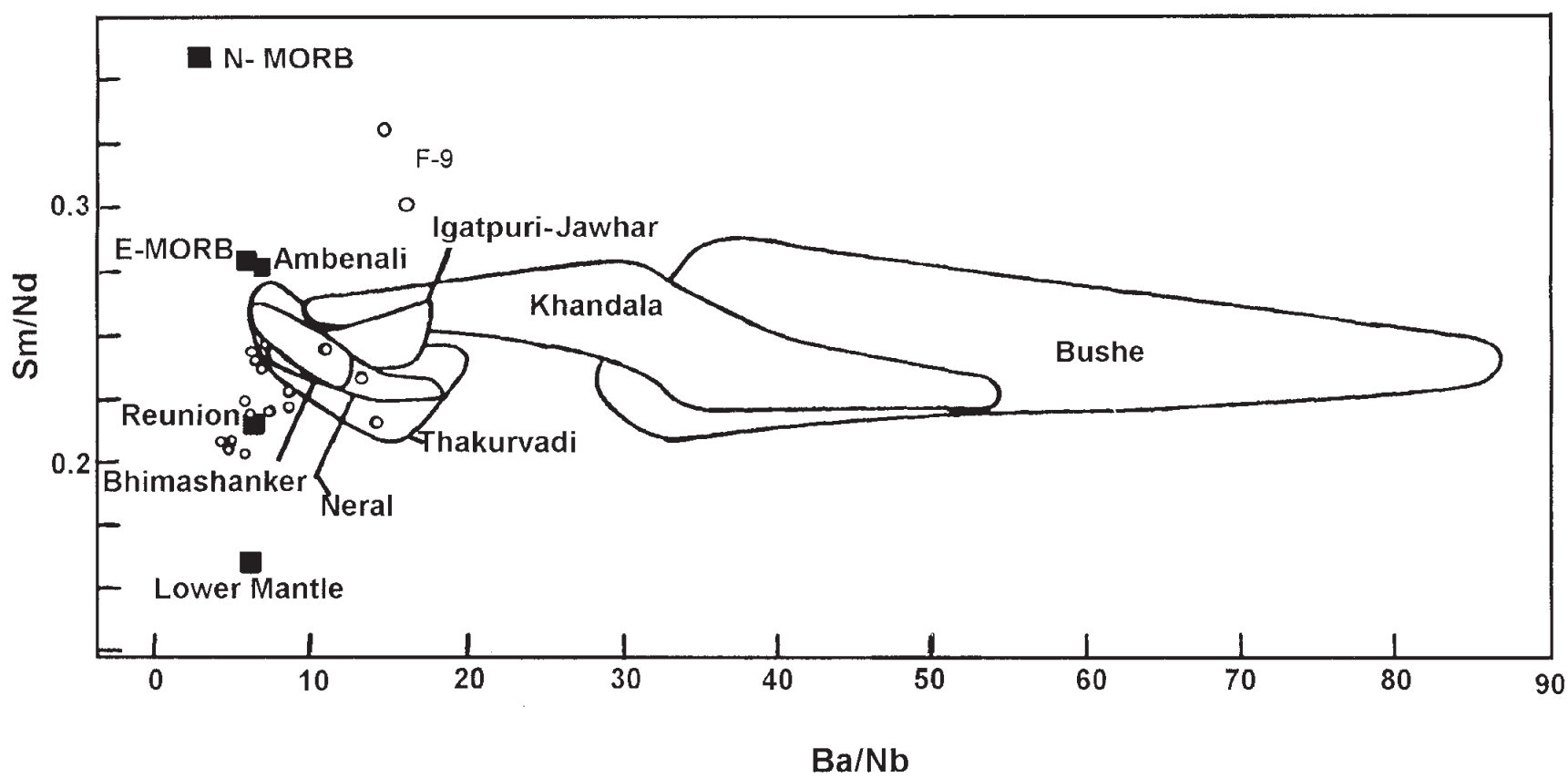

Figure 11. The Sm/Nd vs. Ba/Nb ratio plot reproduced from Peng et al (1994). The data of Anjar flows (open circles) except F-9 lie close to Réunion basalt data.

to be a unique section for studying the relation of Deccan volcanism to the $\mathrm{K} / \mathrm{T}$ boundary. Further study of isotopic ( $\mathrm{Pb}-\mathrm{Sr}-\mathrm{Nd})$ systematics may be useful in understanding its origin and relation to the Réunion plume.

\section{Acknowledgements}

We thank. P Krishnamurthy, K Pande, T R Venkatesan and H C Sheth for several useful suggestions and discussions. One series of samples were collected jointly with the French group of Y Gallet, R Rocchia, C Hofmann and G Feraud, to whom we are grateful for a fruitful field study. We also express our gratitude to V Courtillot and the Geological Survey of India for their collaboration during many stages of this work. We thank Nora S Alsop of the United States Department of Interior for kindly providing us several USGS reference standards for INAA studies.

\section{References}

Allègre C J, Birck J L, Capmas F and Courtillot V 1999 Age of the Deccan traps using ${ }^{187} \mathrm{Re}^{-{ }^{187}}$ Os systematics; Earth Planet. Sci. Lett. 170 197-204

Alvarez L W, Alvarez W, Asaro F and Michel H V 1980 Extraterrestrial cause of the Cretaceous/Tertiary extinction; Science 208 1095-1108.

Baksi A K 1994 Geochronological studies on whole rock basalts, Deccan Traps: Evaluation of the timing of volcanism relative to the K-T boundary; Earth Planet. Sci. Lett. $12143-56$
Balaram V, Ramesh S L and Anjanaiah K V 1996 New trace element and REE data in thirteen GSF Reference samples by ICP-MS; Geostandards News Letter $\mathbf{2 0}$ 71-78

Balaram V, Ramesh S L and Anjanaiah K V 1995 Comparative study of the sample decomposition procedures in determination of trace and rare earth elements in anorthosites and related rocks by ICP-MS; Fresenius J. Anal. Chem. 353 176-182

Basu A R, Renne P R, Dasgupta D K, Teichmann E and Poreda R J 1993 Early and late alkali igneous pulses and a high ${ }^{3}$ He plume origin for the Deccan flood basalts; Science 261 902-906

Beane J E, Turner C A, Hooper P R, Subbarao K V and Walsh J N 1986 Stratigraphy, composition and form of the Deccan basalts, Western Ghats, India; Bull. Volcanol. 48 61-83

Bhandari N, Gupta M and Shukla P N 1993 Deccan volcanic contribution of Ir and other trace elements near the $\mathrm{K} / \mathrm{T}$ boundary; Chem. Geol. 103 129-139

Bhandari N, Gupta M, Pandey J and Shukla P N 1994 Chemical profiles in K/T Boundary section of Meghalya, India: cometary, asteroidal or volcanic; Chem. Geol. 113 45-60

Bhandari N, Shukla P N, Ghevariya Z G, and Sundaram S M 1995 Impact did not trigger Deccan Volcanism: Evidence from Anjar K/T boundary intertrappean sediments; Geophys. Res. Lett. 22 433-436

Bhandari N, Shukla P N, Ghevariya Z G and Sundaram S M 1996 K/T boundary layer in Deccan intertrappeans at Anjar, Kutch; Geol. Soc. Am. Sp. Pap. 307 417-424

Campbell I H and Griffiths R W 1990 Implications of mantle plume structure for evolution of flood basalts; Earth Planet. Sci. Lett. 99 79-93

Cande S C and Kent D V 1995 Revised calibration of the geomagnetic polarity time scale for the Late Cretaceous and Cenozoic; J. Geophys. Res. 100 6093-6095

Coffin M F and Eldholm O 1993 Large igneous provinces; Sci. Amer. 269 42-49 
Courtillot V, Besse J, Vandamme D, Montigny R, Jaeger J J and Cappetta H 1986 Deccan flood basalts at the Cretaceous-Tertiary boundary; Earth Planet. Sci. Lett. 80 361-374

Courtillot V, Feraud G, Maluski H, Vandamme D, Moreau M G and Besse J 1988 Deccan flood basalts at the Cretaceous/Tertiary boundary; Nature 333 841-843

Courtillot V, Jaeger J J, Yang Z, Feraud G and Hofmann C 1996 The influence of continental flood basalts on mass extinctions : Where do we stand?; Geol. Soc. Am. Spec. Pap. 307 513-525

Cox K G and Hawkesworth C J 1985 Geochemical stratigraphy of the Deccan traps at Mahabaleshwar, Western Ghats, India with implications for open system magmatic processes; J. Petrol. 26 355-387

Deshmukh S S and Nair K K K 1996 Deccan basalts; Gondwana Geological Magazine, Spl. Vol. 2 pp 543

Devey C W and Lightfoot P C 1986 Volcanological and tectonic control of stratigraphy and structure in the western Deccan Traps; Bull. Volcanol. 48 195-207

Duncan R A 1981 Hotspots in the southern oceans, an absolute frame of reference for motion of the Gondwana continents; Tectonophysics $\mathbf{7 4}$ 29-42

Duncan R A and Pyle D G 1988 Rapid eruption of the Deccan flood basalts at the Cretaceous/Tertiary boundary; Nature 333 841-843

Fisk M R, Upton B G J, Ford C E and White W M 1988 Geochemical and experimental study of the genesis of magmas of Réunion Island, Indian Ocean; J. Geophys. Res. 93 4933-4950

Floyd P A and Winchester J A 1975 Magma type and tectonic setting discrimination using immobile elements; Earth Planet. Sci. Lett. 27 211-218

Ghevariya Z G 1988 Intertrappean dinosaurian fossils from Anjar area, Kutch district, Gujarat; Curr. Sci. $57248-$ 251

Ghevariya Z G and Srikarni C 1989 Geology of the Mesozoic formations of Kutch, Gujarat; Records of the Geologic Survey India 121 165-167

Govil P K 1985 X-ray fluorescence analysis of major, minor and selected trace elements in new IWG reference rock samples; J. Geol. Soc. India 26 38-42

Hofmann C 1997 Datation ${ }^{40} \mathrm{Ar} /{ }^{39} \mathrm{Ar}$ et Palaeomagnetisme des Traps d'Ethiopie, du Deccan et de Siberie Unpublished Ph.D Thesis Institut de Physique du Globe de Paris, 200pp.

Hofmann C, Feraud G and Courtillot V $2000{ }^{40} \mathrm{Ar} /{ }^{39} \mathrm{Ar}$ dating of mineral separates and whole rocks from Western Ghats lava pile: further constrains on duration and age of the Deccan traps; Earth Planet. Sci. Lett 180 13-28

Izett G A, Dalrymple G B and Snee L W $1991{ }^{40} \mathrm{Ar} /{ }^{39} \mathrm{Ar}$ ages of Cretaceous/Tertiary Boundary tektites from Haiti; Science 252 1539-1542

Kaneoka I, Naoyoshi I, Keisuke N and Deshmukh S S 1996 Period of volcanic activity of the Deccan plateau inferred from K-Ar ages and problem related to radiometric dating. In: Deccan Basalts (eds) S S Deshmukh and K K K Nair Gondwana Geological Magazine, Sp.Vol. 2 311-320

Khadkikar A S, Sant D A, Gogte V and Karanth R V 1999 The influence of Deccan volcanism on palaeoclimate during $\mathrm{K} / \mathrm{T}$ : insights from lacustrine intratrappean deposits, Anjar, western India; Palaegeogr. Palaeoclim. Palaeoeco 147, 141-148

Khadri S F R, Subbarao K V and Bodas M S 1988 Magnetic studies on a thick pile of Deccan Trap flows at Kalsubai; In: Deccan Flood basalts (ed) K V Subbarao Geological Society of India Mem. 10 163-180
Krishnamurthy P and Cox K G 1977 Picrite basalts and related lavas from Deccan Traps of western India; Contrib. Mineral. Petrol. 62 53-75

Krishnamurthy P and Cox K G 1980 A potassium-rich alkalic suite from Deccan Traps, Rajpipla, India; Contrib. Mineral. Petrol. 73 479-489

Krishnamurthy P, Pande K, Gopalan K and Macdougall J D 1988 Upper mantle xenoliths in alkali basalts related to Deccan Trap volcanism; In: Deccan Flood Basalts (ed) K V Subbarao Geol. Soc. India, Mem. 10 53-68

Lerbekmo J F and Sweet A R 1994 A short normal magnetic interval at the $\mathrm{K} / \mathrm{T}$ boundary: A measure of continuity of record across the boundary and synchroneity of boundary events; In : New developments regarding the KT events and other Catastrophes in Earth's History, LPI Contribution 825, Lunar and Planetary Institute, Houston, 138 pp 66-67

Lightfoot P C, Hawkesworth C J, Devey C W, Rogers N W and van Calsteren P W C 1990 Source and differentiation of Deccan Trap lavas: implications of geochemical and mineral chemical variations; J. Petrol. 31 1165-1200

Mahoney J J 1988 Deccan Traps; In: Continental flood basalts (ed) J D Macdougall Dordrecht, Kluwer Academic, 151-194

Melluso L, Beccaluva L, Brotzu P, Gregnanin A, Gupta A K, Morbidelli L and Traversa G 1995 Constraints on the mantle source of the Deccan Traps from the petrology and the geochemistry of the basalts of Gujarat state (western India); J. Petrology 36 1393-1432

Meschede M 1986 A method of discrimination between different types of mid-ocean ridge basalts and continental tholeiites with the Nb-Zr-Y diagram; Chem. Geol. 56 207-218

Morgan W J 1972 Plate motions and deep mantle convection; Geol. Soc. Amer. Mem. 132, 7-22

Morgan W J 1981 Hotspot tracks and opening of the Atlantic and Indian Oceans. In: The Sea (ed) C Emiliani; Wiley, New York, 443-487

Mullen E D 1983 MnO- $\mathrm{TiO}_{2}-\mathrm{P}_{2} \mathrm{O}_{5}$ : a minor element discriminant for basaltic rocks of oceanic environments and its implications for petrogenesis; Earth Planet. Sci Lett. $6253-62$

Orth C J, Attrep M Jr and Quintana L R 1990 Iridium abundances patterns across bio-event horizons in the fossil record; Geol. Soc. Am. Sp. Pap. 247 45-60

Pande K, Venkatesan T R, Gopalan K, Krishnamurthy P and Macdougall J D $1988{ }^{40} \mathrm{Ar}-{ }^{39} \mathrm{Ar}$ ages of alkali basalts from Kutch, Deccan Volcanic province, India; In: Deccan Flood Basalts (ed) K V Subbarao Geol. Soc. India 10 $145-150$

Pande K 1988 Isotopic and chemical studies of ultramafic nodules in alkali basalts from Kutch, western India; Unpublished Ph D Thesis, Physical Research Laboratory, Ahmedabad, India, 136pp

Pearce J A and Cann J R 1973 Tectonic setting of basic volcanic rocks determined using trace element analysis; Earth Planet. Sci. Lett. 19 290-300

Pearce T H, Gorman B E and Birkett T C 1975 The $\mathrm{TiO}_{2}$ $\mathrm{K}_{2} \mathrm{O}-\mathrm{P}_{2} \mathrm{O}_{5}$ diagram: a method of discriminating between oceanic and non-oceanic basalts; Earth Planet. Sci. Lett. 24 419-426

Pearce J A and Norry M J 1979 Petrogenesis implications of $\mathrm{Ti}, \mathrm{Zr}, \mathrm{Y}$ and $\mathrm{Nb}$ variations in volcanic rocks; Contrib. Mineral. Petrol. 69 33-47

Pearce J A 1980 Geochemical evidence for the genesis and eruptive setting of lavas from Tethyan ophiolites; Proc. Int. Ophiolite Symp. Cyprus 1979; Institute of Mining and Metallurgy 261-272 
Peng Z X and Mahoney J J 1995 Drillhole lavas from the northwestern Deccan Traps and evolution of Réunion hotspot mantle; Earth Planet. Sci. Lett. 134 169-185

Peng Z X, Mahoney J J, Hooper P R, MacDougall J D and Krishnamurty P 1998 Basalts of the northeastern Deccan traps, India: Isotopic and elemental geochemistry and relation to southwestern Deccan stratigraphy; J. Geophys. Res. 103 29843-29865

Peng Z X, Mahoney J J, Hooper P R, Harris P G and Beane J A 1994 A role for continental crust in flood basalt genesis? Isotopic and incompatible element study of the lower six formations of western Deccan Traps; Geochim. Cosmochim. Acta 58 267-288

Raju D S N, Jaiprakash B C, Kumar A, Saxena R K, Dave A, Chatterjee T K and Mishra C M 1995 Age of Deccan volcanism across KTB in Krishna-Godavari basin, New evidences; J. Geol. Soc. India 45 229-233

Raju D S N, Ravindran V N, Dave A, Jaiprakash B C and Singh J $1991 \mathrm{~K} / \mathrm{T}$ boundary events in Cauvery and Krishna-Godavari basins and the age of Deccan volcanism; Geoscience J. 12 177-190

Rocchia R, Boclet D, Courtillot V and Jaeger J J 1988 A search for iridium concentration in the Deccan traps and intertraps; Geophys. Res. Lett. 15 812-815

Sano T and Fujii T 1996 Chemical variation of the uncontaminated (Ambenali-like) basalts of Deccan Traps; In: Deccan Basalts; (eds) S S Deshmukh and K K K Nair Gondwana Geol. Mag. Spl. Vol. 2 301-310

Sen G 1995 A simple petrologic model for the generation of Deccan Trap magmas; Int. Geol. Rev. 37 825-850

Shekhawat L S and Sharma V P 1996 Deccan Basalts of Wankaner-Rajkot area, Gujarat, In: Deccan Basalts; (eds) S S Deshmukh and K K K Nair Gondwana Geological Magazine, Spl. Vol 2 89-100

Shrivastava J P, Salil M S and Pattanayak S K 2000 Clay mineralogy of Ir-bearing Anjar intertrappeans, Kutch, Gujarat, India: inferences on palaeoenvironment; J. Geol. Soc. India 55 197-206

Shukla P N, Shukla A D and Bhandari N 1997 Geochemical characterisation of the Cretaceous-Tertiary boundary sediments at Anjar, India; Palaeobotanist 46 (1,2) 127132

Shukla P N, Venkatesan T R and Bhandari N 1988 Chemistry and chronology of traps and intertrappeans from Takli, Nagpur; In: Deccan Flood Basalts (ed) K V Subbarao Geol. Soc. India, Mem. 10 213-223
Shukla P N and Bhandari N 1997 Physical, chemical and biological changes at geological boundaries: causes, consequences and clues based on the study of Indian sections; Palaeobotanist 46 (1, 2) 41-62

Sreenivasa Rao M N, Ramasubba Reddy, Subbarao K V, Prasad C V R K and Radhakrishnamurthy C 1985 Chemical and magnetic stratigraphy of parts of Narmada region, Deccan basalt province; J. Geol. Soc. India $\mathbf{2 6}$ $617-639$

Subbarao K V, Bodas M S, Hooper P R and Walsh J N 1988 Petrogenesis of Jawhar and Igatpuri Formations, Western Deccan Basalt Province, India; In: Deccan Flood Basalts (ed) K V Subbarao Geol. Soc. India. Mem. 10 253-280

Vandamme D, Courtillot V, Besse $\mathrm{J}$ and Montigny $\mathrm{R}$ 1991 Palaeomagnetism and age determinations of Deccan traps: results of a Nagpur-Bombay traverse and review of earlier work; Rev. Geophys. 29 159-190

Venkatesan T R and Pande K 1996 A review of ${ }^{40} \mathrm{Ar}^{39}{ }^{39} \mathrm{Ar}$ Ages from the Western Ghats, Deccan Trap Province, India: Implication for $\mathrm{K} / \mathrm{T}$ events; In: Deccan basalts, (eds) S S Deshmukh and K K K Nair Gondawana Geol. Mag. Spl.Vol. 2 321-328

Venkatesan T R, Pande K and Ghevariya Z G 1996 ${ }^{40} \mathrm{Ar} /{ }^{39} \mathrm{Ar}$ ages of Anjar Traps, western Deccan Province (India) and its relation to Cretaceous-Tertiary boundary events; Curr. Sci. 70 990-996

Venkatesan T R, Pande K and Gopalan K 1993 Did Deccan volcanism pre-date the Cretaceous/Tertiary transition?; Earth Planet. Sci. Lett. 119 181-189

Winchester J A and Floyd P A 1977 Geochemical discrimination of different magma series and their differentiation products using immobile elements; Chem.Geol. 20 325343

Wood D A 1980 The application of a Th-Hf-Ta diagram to problems of tectonomagmatic classification and to establishing the nature of crustal contamination of basaltic lavas of the British Tertiary Province; Earth Planet. Sci. Lett. 50 11-30

Yedekar D B, Aramaki S, Fujii T and Sano T 1996 Geochemical signature and stratigraphy of the ChhindwaraJabalpur-Seoni-Mandala sector of the eastern Deccan volcanic province and problems of its correlation; In Deccan Basalts; (eds) S S Deshmukh and K K K Nair Gondawana Geol. Mag. Spl.Vol. 2 49-68 